\title{
Iglesia San José, San Juan, Puerto Rico: perspectiva arqueológica a cinco siglos de su historia constructiva
}

\section{San José Church, San Juan, Puerto Rico: Archaeological Perspective of Five Centuries of its Constructive History}

\author{
Jorge A. Rodríguez López ${ }^{1}$ \\ Centro de Estudios Avanzados de Puerto Rico y el Caribe \\ Juan M. Rivera Groennou²
}

\begin{abstract}
RESUMEN
La investigación de Arqueología de la Arquitectura en la Iglesia San José, San Juan de Puerto Rico, se enmarcó en el proyecto de restauración que lleva a cabo actualmente el Patronato de Monumentos de San Juan Inc. Dicha investigación se enfocó en analizar el desarrollo de las diferentes técnicas y materiales constructivos asociados al s. XVI: ábside, crucero y transepto. Entre sus objetivos estuvieron: aportar información sobre las técnicas y materiales constructivos utilizados; aportar criterios científicos que permitieran identificar la extensión y límites de cada una de sus fases y etapas constructivas. Los resultados permitieron la identificación de diversas técnicas constructivas utilizadas, así como una delimitación precisa de su configuración a lo largo de sus casi 500 años. Estos resultados presentan una perspectiva mucho más dinámica sobre los procesos constructivos del inmueble y confirman la necesidad de estudios arqueológicos en obras de restauración de edificios patrimoniales.
\end{abstract}

Palabras clave: Arqueología de la Arquitectura; Convento de los Dominicos; análisis de fábricas; secuencias constructivas; siglo XVI.

\section{ABSTRACT}

The research of Archeology of Architecture in the San José Church, San Juan in Puerto Rico, was part of the restoration project currently carried out by the Patronato de Monumentos of San Juan Inc. This research focused on analyzing the development of the different construction techniques and materials associated with the $16^{\text {th }}$ century: apse, central nave and transept. The main objectives intended to provide information on the techniques and construction materials used; and to offer scientific criteria to identify the extension and limits of every phase and building stage. The results allowed to identify the different building techniques used, as well as to precisely delimitate its configuration throughout its almost 500 years. These results presented a much more dynamic perspective on the constructive processes of the building and confirmed the need for archaeological studies within the frame of the restoration works of heritage buildings.

Key words: Archaeology of Architecture; Dominican monastery; construction analysis; construction sequences; $16^{\text {th }}$ century.

Recibido: 03-06-2020. Aceptado: 10-12-2020. Publicado: 14-04-2021

Cómo citar este artículo / Citation

Rodríguez López, J. A. y Rivera Groennou, J. M. 2021: "Iglesia San José, San Juan, Puerto Rico: perspectiva arqueológica a cinco siglos de su historia constructiva", Arqueología de la Arquitectura, 18: e115. https://doi.org/10.3989/arq.arqt.2021.007

Copyright: (C) CSIC, 2021. (C) UPV/EHU Press, 2021. Este es un artículo de acceso abierto distribuido bajo los términos de la licencia de uso y distribución Creative Commons Reconocimiento 4.0 Internacional (CC BY 4.0).

jarlopr@live.com / ORCID iD: https://orcid.org/0000-0003-4797-1421

riveragroennou@gmail.com / ORCID iD: https://orcid.org/0000-0002-2277-5232 
La Iglesia San José constituye uno de los hitos arquitectónicos más importantes y antiguos de Puerto Rico, el Caribe y de América (Fig. 1). Localizada en la capital de Puerto Rico, el Viejo San Juan (Fig. 2), su construcción comenzó en 1532 como iglesia conventual de la orden de los dominicos, fue desde sus inicios patronato de la familia García Troche y luego de los Ponce de León Troche (Hostos 1979). Su estilo gótico isabelino fue muy característico de la etapa temprana de la colonización española en América (Damiani Cósimi 1994) y sus elementos más notables son sus bóvedas góticas hechas en sillería (Buchiazzo 1955; Campo Lacasa 1961; Castro 1980). Sin embargo, esta imponente estructura, una de las más antiguas en Hispanoamérica, fue el resultado de varios procesos constructivos que abarcaron un periodo de aproximadamente 250 años hasta alcanzar su fisonomía actual. A esto se le añaden otros procesos de modificaciones

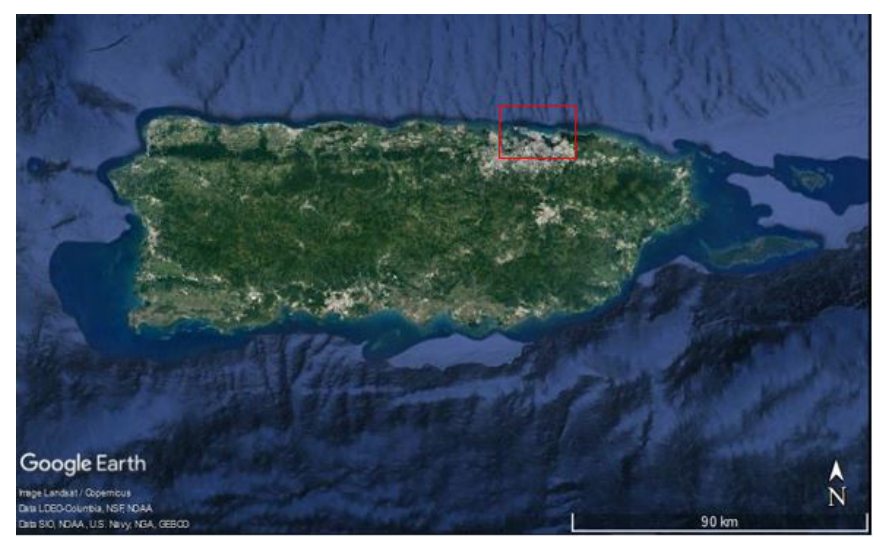

Figura 1. Imagen de satélite de la isla de Puerto Rico. En el recuadro, San Juan. Imagen Google Earth.

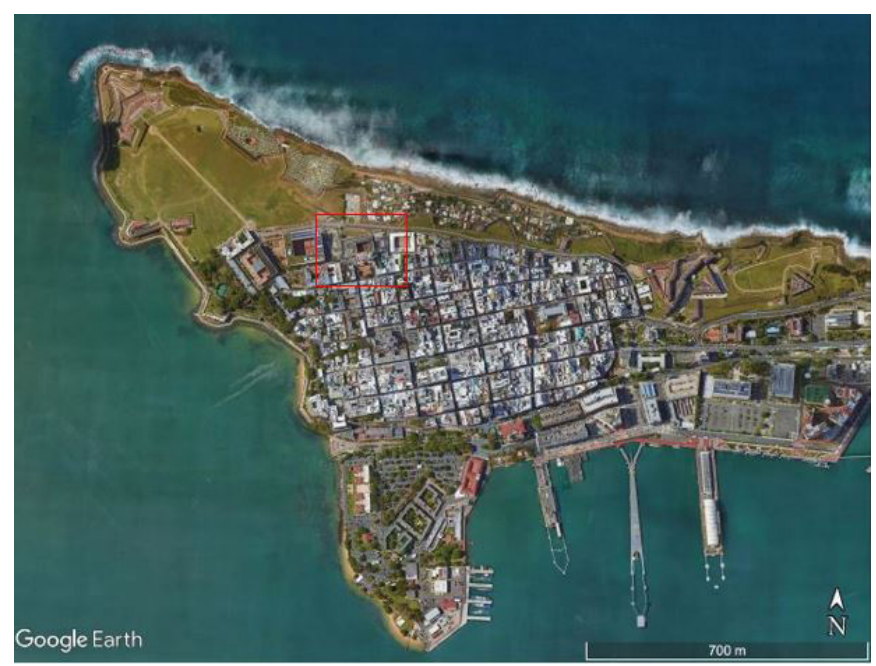

Figura 2. Imagen de satélite de San Juan de Puerto Rico. Imagen Google Earth. menores que abarcaron un periodo de cerca de 150 años adicionales (Fig. 3).

El solar donde se ubica fue donado por el conquistador y gobernador de la isla Juan Ponce de León, y posteriormente su construcción fue iniciada por su yerno Garci Troche (Murga Sanz 1964: 142-144). Durante su primera etapa como iglesia del convento de los dominicos estuvo consagrada a Santo Tomás de Aquino, esta orden religiosa estuvo a cargo de sus sucesivas obras de construcción durante los 337 años de su permanencia en Puerto Rico (Cuesta Mendoza 1946). Es durante esta etapa que la iglesia adquirió su fisonomía actual, salvo adiciones menores. En 1858 la orden es obligada a abandonar la isla, año en que la Compañía de Jesús toma posesión del complejo, monasterio e iglesia, consagrándola a San José. Durante este periodo se realizaron varias modificaciones adicionales que alteraron limitadamente la configuración del inmueble.

\section{ARQUEOLOGÍA DE LA ARQUITECTU- RA EN EL VIEJO SAN JUAN}

Este trabajo busca contribuir a la puesta al día de las investigaciones de la arqueología de la arquitectura en el Viejo San Juan utilizando como caso de estudio la Iglesia San José. En dicha investigación se realizaron importantes hallazgos sobre las técnicas constructivas empleadas a partir del s. XVI hasta principios del XX, que fueron identificadas previamente en otras edificaciones emblemáticas de la ciudad como Casa Blanca.

Con los resultados obtenidos en el Proyecto de Investigación de Casa Blanca se estableció una tipología de técnicas constructivas con sus respectivas asociaciones cronológicas enmarcándose el desarrollo del inmueble en cuatro fases históricas y doce etapas constructivas (Rivera Fontán et al. 2011; 2013; 2014; Rivera Groennou et al. 2011; Rodríguez López et al. 2015). Como parte de estos estudios se analizaron y tipificaron formas de elaboración de morteros de fábrica asociados a cada tipo de técnica constructiva y sus cambios en dosificación a nivel cronológico (Rivera Groennou et al. 2015).

Entre las técnicas más destacables identificadas en Casa Blanca se encontraron muros de tapia, mampostería ordinaria encadenada en sillares y mampostería careada con verdugadas de ladrillos. Utilizando pruebas arqueológicas y documentación histórica estos tipos de muros fueron enmarcados cronológicamente: tapia aso- 

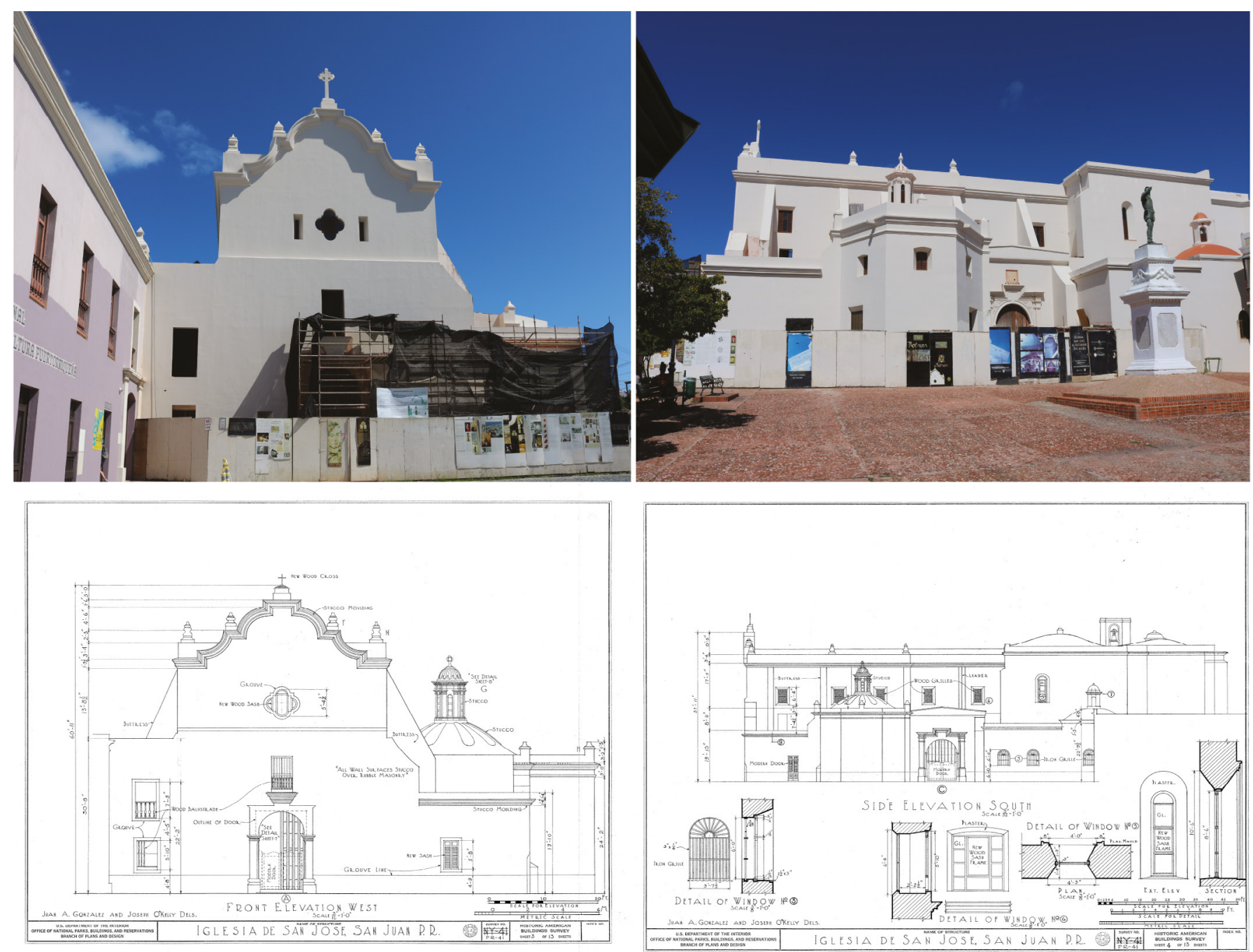

Figura 3. Parte superior: varias perspectivas de las condiciones actuales de la iglesia: izquierda, fachada principal; derecha, fachada sur; dibujos a escala de las mismas fachadas de las fotos superiores. Fuente: Historic American Buildings Survey. US Department of Interior, National Park Service. Survey No. PR-41. Index No. 7-SAJU-1.

ciada al s. XVI; mampostería ordinaria encadenada en sillares al s. XVIII; y la mampostería careada con verdugadas de ladrillos al s. XIX. Al igual que en San José, en Casa Blanca se identificaron otras técnicas constructivas comunes como la mampostería ordinaria, las cuales tuvieron un uso continuo a lo largo de sus fases históricas y etapas constructivas (Fig. 4).

Siguiendo lo que fue nuestra propuesta de intervención para Casa Blanca, en la Iglesia San José se identificaron y definieron otras técnicas mixtas que no habían sido documentadas previamente. Todas sus estructuras y correspondientes técnicas constructivas fueron enmarcadas dentro de un esquema de desarrollo constructivo que abarcó siete etapas constructivas (Rodríguez López y Rivera Groennou 2016). Al igual que en Casa Blanca, ciertas técnicas constructivas fueron características para determinadas etapas, donde tuvieron un papel protagónico los muros de tapia con sus diferentes variaciones y las bóvedas góticas en sillería.

No obstante, al momento de abordar la investigación arqueológica de la Iglesia San José se confrontaron varios problemas fundamentales. Primero, a pesar de que este inmueble ha sido intervenido en numerosas ocasiones desde la década de 1960, existía muy escasa información o reportes técnicos de condiciones o hallazgos. Estas intervenciones incluyeron extensivas excavaciones en el interior de todas las áreas del inmueble, incluyendo el convento de los dominicos, las cuales produjeron muy poca información relacionada al desarrollo constructivo del inmueble. Estos estuvieron más orientados a los componentes artefactuales recuperados (Rodríguez s. a.: 84). 

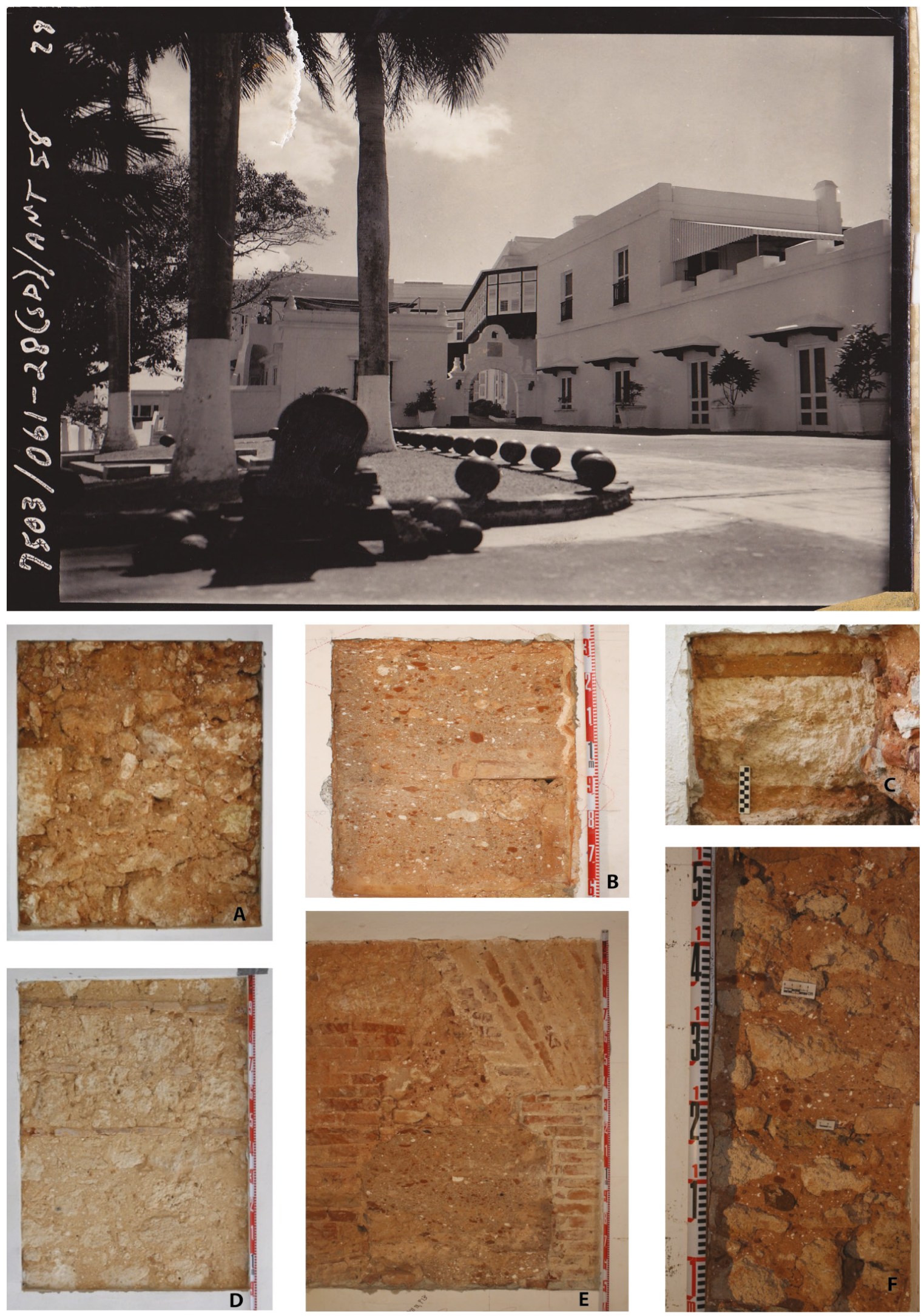

Figura 4. Parte superior: vista de Casa Blanca hacia el sureste, 7 de julio de 1958. Archivos del San Juan National Historic Site, National Park Service (SJNHS), Foto 712. Parte inferior: tipos de muros identificados en Casa Blanca; A: mampostería ordinaria encadenada en sillares; B: tapia; C: detalle sillares; D: mampostería careada con verdugadas; E: secuencia estratigráfica denominada "Piedra Rossetta" Salón XII; F: mampostería ordinaria. 
Otras intervenciones incluyeron reparaciones de revestimientos y cegamientos de vanos con materiales contemporáneos como el cemento y bloques de agregados. Estas estuvieron más dirigidas a resolver problemas inmediatos del inmueble que a atender aspectos de investigación científica. Sin embargo, estas intervenciones no atendieron diversos problemas que aquejaban al edificio y este fue clausurado en 1993, debido principalmente a que existía la preocupación ante el posible fallo estructural de la bóveda gótica principal que cubre el transepto.

No es hasta el año 2004 que se inició un proceso de análisis y diagnóstico dirigido a identificar las diversas patologías que sufría la iglesia a causa de la humedad y las filtraciones como fase inicial de un proyecto de restauración (Fundación para la Arquitectura 2010). Durante los años 2004-2007 se realizaron otros estudios que incluyeron la realización de estudios de prospección remota (GPR) y la generación de imágenes 3D con rayos láser para medir el interior de la iglesia para diseñar y construir un andamio para apuntalar la bóveda gótica central (ibid.). Con el establecimiento de un proyecto piloto de restauración para la Capilla del Rosario, que incluía la restauración de sus frescos, la remoción de los revestimientos de cemento para ser sustituidos por morteros de restauración; inició un proyecto más amplio que continúa hoy.

Segundo, aun con todo el rigor empleado en estos trabajos, el equipo restaurador no consideró incluir los elementos metodológicos de la Arqueología de la Arquitectura, por lo que aún carecía de información estratigráfica que analizara la secuencia constructiva de San José. Aun cuando el equipo de restauración preparó un esquema de desarrollo constructivo para San José (ibid: 28-31), su principal limitación estaba en que fue elaborado estrictamente a partir de información histórica y documental y no en la caracterización de fábricas, como tampoco en la elaboración de secuencias estratigráficas que permitieran establecer las relaciones secuenciales entre sus diferentes estructuras. Esta información se hizo particularmente relevante para abordar las reparaciones de la bóveda gótica, ya que la pregunta fundamental del equipo de arquitectos e ingenieros estructurales estaba dirigida a cuál era la relación secuencial entre las diferentes bóvedas del componente del s. XVI. Es decir, si fueron construidas durante un mismo evento o si ocurrió en varias fases.

Este tipo de intervención implementada en San José ha sido muy característico en numerosas estructuras del Viejo San Juan. A pesar de que se ha insistido en la necesidad de contar con equipos multidisciplinarios que incluyan arquitectos, arqueólogos, conservacionistas, su aplicación ha relegado el papel de la arqueología a atender exclusivamente los aspectos asociados a la interpretación de rellenos bajo nivel de suelo (Rivera Groennou et al. 2015: 764). Y en los casos en que equipos de arqueología participaron de forma más directa en aspectos de muestreo de fábricas, las mismas estuvieron centradas en la restauración de estos edificios utilizando materiales más compatibles, que en interpretaciones de su desarrollo constructivo (López Sotomayor 2000).

Es a partir de este trasfondo de lo que ha sido la práctica de la intervención de edificios históricos que adquieren mayor relevancia nuestros trabajos previos en Casa Blanca y en la información sobre las técnicas constructivas, secuencias estratigráficas descubiertas en San José.

\section{METODOLOGÍA DE INVESTIGACIÓN}

La investigación arqueológica se abordó considerando el desarrollo de las diferentes técnicas y materiales constructivos. Se prestó particular atención al componente asociado al s. XVI de la Iglesia San José: ábside, crucero y transepto; principalmente a la comprensión de sus secuencias constructivas y su relación estratigráfica con las bóvedas góticas hechas sillería. Por tanto, la investigación se centró en entender las secuencias constructivas de estos componentes del inmueble y su relación estratigráfica con las bóvedas góticas hechas sillería.

Los objetivos generales del estudio de Arqueología de la Arquitectura llevado a cabo en la Iglesia San José fueron:

1. Caracterización de las técnicas y materiales constructivos utilizados en el edificio a través del tiempo.

2. Entender la transformación constructiva y arquitectónica de la Iglesia San José.

3. Establecer fases y etapas constructivas mediante la caracterización de técnicas y materiales constructivos para entender las transformaciones del inmueble a lo largo del tiempo.

4. Establecer criterios científicos para identificar la extensión y límites de cada una de las fases y etapas constructivas del inmueble.

5. Obtener datos de los materiales de construcción, fases y etapas para entender las soluciones de continuidad empleadas entre etapas constructivas. 
El acercamiento teórico y metodológico se fundamentó en los preceptos establecidos para la intervención de estructuras patrimoniales desde la perspectiva de la Arqueología de la Arquitectura (Parenti 1992; Azkarate et al. 2002; Mileto y Vegas 2003; Quirós Castillo 2002; Harris 1991; Cerdá y García Bonafé 1995; Brogiolo 2002; Caballero Zoreda 2002; Tabales Rodríguez 1997, 2002). Dada la monumentalidad del inmueble, se trazó una estrategia de investigación que incluyó perspectivas históricas, arqueológicas y arquitectónicas. Estas se diseñaron tomando en consideración las dimensiones del área, complejidad de las estructuras a estudiar y el número de elementos constructivos y arquitectónicos identificados.

El análisis de las construcciones que definieron el edificio de la Iglesia de San José, se basó en el estudio de los paramentos (Azkarate et al. 2002; Mileto y Vegas 2003; Quirós Castillo 2002). El estudio secuencial constructivo se fundamentó a partir del método estratigráfico desarrollado por Eduard Harris (1991). Este estudio se basa en establecer correlaciones entre los diferentes cuerpos de fábrica, sus intervenciones, tipos y dirección de adosamientos, y los rellenos depositados en el entorno de las edificaciones construidas en albañilería.

Desde esta perspectiva, se concibió el edificio como un recipiente tridimensional compuesto por su cimentación, cuerpos de fábrica y los revestimientos (Parenti 1992). Se utilizaron como herramientas fundamentales para la correlación de la secuencia estratigráfica: (1) las técnicas constructivas y (2) los materiales empleados para su puesta en obra. Se crearon tipologías y las caracterizaciones de ambos elementos (técnicas y materiales) permitieron el establecimiento de secuencias constructivas para el complejo edilicio (Brogiolo 2002; Caballero Zoreda 2002; Tabales Rodríguez 1997, 2002).

Los trabajos en la Iglesia San José se centraron en el análisis de fábricas de las principales estructuras de cerramiento o muros que dan forma a la parte más antigua de la iglesia. La investigación se enfocó en los muros de carga o aquellas paredes del edificio que poseen funciones estructurales. Es decir, aquellas estructuras que soportan otros elementos estructurales del edificio, como arcos, bóvedas, entre otros.

En la Iglesia San José se aplicó el concepto de unidades estratigráficas murarias (UEM) como categoría principal de análisis (Cerdá y García Bonafé 1995) para el estudio estratigráfico de las distintas estructuras y tipos de fábricas documentadas. A partir del estudio de fábricas se identificaron las UEM a partir de la caracterización de las técnicas y materiales constructivos utilizados en su alzado. También se enfatizó en la identificación y estudio de los sistemas de adosamientos y de las relaciones estratigráficas de elementos constructivos documentados. Este análisis permitió determinar el carácter de las construcciones, remodelaciones y reparaciones realizadas de las estructuras.

El estudio secuencial, siguiendo el método estratigráfico, se realizó en dos direcciones: (1) en sentido horizontal y (2) vertical. Para el estudio a nivel horizontal se agruparon la secuencia de engrosamientos y demás revestimientos sobre las fábricas. Por otro lado, para el estudio a nivel vertical donde se agrupan los principales cuerpos de fábricas y secuencias de remodelaciones. Considerando ambos métodos, la estratigrafía muraria se interpretó tomando en consideración el tipo de estructura construida, los trabajos que se realizaron para su construcción y, por último, los tipos de dirección de los adosamientos.

\section{TÉCNICAS CONSTRUCTIVAS Y TIPO- LOGÍAS DE MUROS}

A lo largo de la historia de la Iglesia San José se emplearon distintas técnicas constructivas en su edificación, siendo la mampostería, en distintas variaciones, la técnica más utilizada. Destaca también la riqueza del trabajo de sillería. Para la construcción de los muros más antiguos de la iglesia se utilizaron varias técnicas mixtas; sillería, mampostería, tapiería y ladrillos en el alzado de un mismo muro. Cabe destacar que la tapiería es una de las técnicas constructivas más antiguas de la iglesia, encontrada únicamente en las paredes que sostienen las bóvedas góticas del s. XVI.

Aun cuando se desconoce el maestro de obras para la iglesia gótica, se le vincula a otras edificaciones análogas por cronología y similitudes estilísticas, con las catedrales de San Juan y Santo Domingo. Bajo esas consideraciones se ha señalado al santanderino Rodrigo de Liendo, también conocido como Rodrigo Gil Rozillo, autor de importantes obras en la ciudad de Santo Domingo como el Monasterio de Las Mercedes, la muralla y la catedral (Flores Sasso 2006). Sin embargo, creemos poco probable que el maestro haya participado en las obras de construcción de las bóvedas góticas ya que vivió en la ciudad de Santo Domingo desde 1525 hasta su muerte en 1556 (ver Flores Sasso 2006 y Robiou 2004). Entre otros maestros mencionados se encontraron el cantero Diego de Arroyo y los albañiles Antón y Alonso Gutiérrez Na- 
varrete, todos sevillanos, contratados por un término de cuatro años con un sueldo de 70 ducados anuales para laborar en Puerto Rico y Santo Domingo (Castro 1980). Lo que sí resulta evidente de las similitudes estilísticas de estas tres edificaciones como exponentes del gótico isabelino en América, es que son representativas de una tendencia transicional, aunque algo tardía, entre el gótico y las nuevas manifestaciones renacentistas traídas por estos maestros constructores.

Durante el s. XVI, la Casa de Contratación de Sevi1la fue la institución encargada de regular el comercio con las posesiones de ultramar, situación que benefició grandemente el comercio de esa ciudad. Como parte de ese tráfico algunas de estas variaciones en las técnicas de elaboración de la tapia empleadas en la construcción de edificios para el San Juan del s. XVI (para aquel entonces Ciudad de Puerto Rico) fueron traídas por los maestros de obras procedentes de España, particularmente desde Sevilla.

La tapiería es una de las técnicas más utilizadas en la construcción de las primeras edificaciones en la ciudad de San Juan desde su fundación en 1521 (Rivera Fontán et al. 2011; Rivera Groennou et al. 2011, 2014; Rodríguez López et al. 2015). En el Censo de 1530 realizado por Francisco de Lando, a pesar de que pregunta sobre las "casas de piedra" que existían en San Juan, varios de los vecinos entrevistados describen la existencia de edificios construidos en tapería. Por ejemplo, destacan la casa del Rey, la casa de Garci Troche (Casa Blanca), la casa de Cristóbal Guzmán, la casa de Obispo, la Iglesia Mayor (Catedral) y la Ermita de Santa Bárbara. ${ }^{3}$ Años más tarde, en la Memoria hecha por el Capitán Juan de Melgarejo en 1582, gobernador de la isla de Puerto Rico, se describe que

... la forma y edificio de las casas de la cibdad de Puertorrico son alguna $[\ldots]$ de tapieria y ladrillo, los materiales con que se hacen las dichas casas son de barro colorado, arenisca y cal y tosca de piedra, hacerse tan fuerte mezcla desto que es más fácil romper una pared de cantería que una tapia desta. ${ }^{4}$

\footnotetext{
Damiani Cósimi, J. 1994 "Información referente al Partido de Puerto Rico" [1530], Editor, Cuadernos de Investigación Histórica, 1. pp. 37-154. Universidad de Puerto, Río Piedras.

4 Coll y Toste, C. 1914: "Memoria y descripción de la isla de San Juan de Puerto Rico mandada a hacer por S.M. el Rey Don Felipe II en el año 1582", Editor, Boletín Histórico de Puerto Rico, Volumen 1, Tomo 1, pp. 75-91. Tip. Cantero, Fernández \& Co. San Juan.
}

En la Iglesia San José el tipo de tapiería descrita en la Memoria de Melgarejo se utilizó en el alzado de los muros del ábside y transepto. En estos salones, los cajones de tapia alcanzan dimensiones de aproximadamente dos metros de largo, por noventa centímetros de alto y hasta un metro de ancho $(2 \times 0,9 \times 1 \mathrm{~m})$. En los paramentos se observan los huecos cuadrados o mechinales, de no más de $15 \times 15 \mathrm{~cm}$ y rematados en su parte superior por un ladrillo, para las agujas de madera utilizadas para apoyar y dar sujeción a los tapiales (Fig. 5).

Considerando la procedencia sevillana de los maestros artesanos involucrados en la construcción de San José y siguiendo el esquema cronotipológico desarrollado por Graciani García y Tabales Rodríguez, no nos sorprende que tipos de tapia identificados en San José coincidan con algunos identificados por estos en el área sevillana (2008). Entre los tipos identificados en San José similares a sus contrapartes sevillanos se encontraron los tapiales de fraga encadenados en piedra con verdugadas de ladrillos y su variante con remate latericio (2008: 138-139).
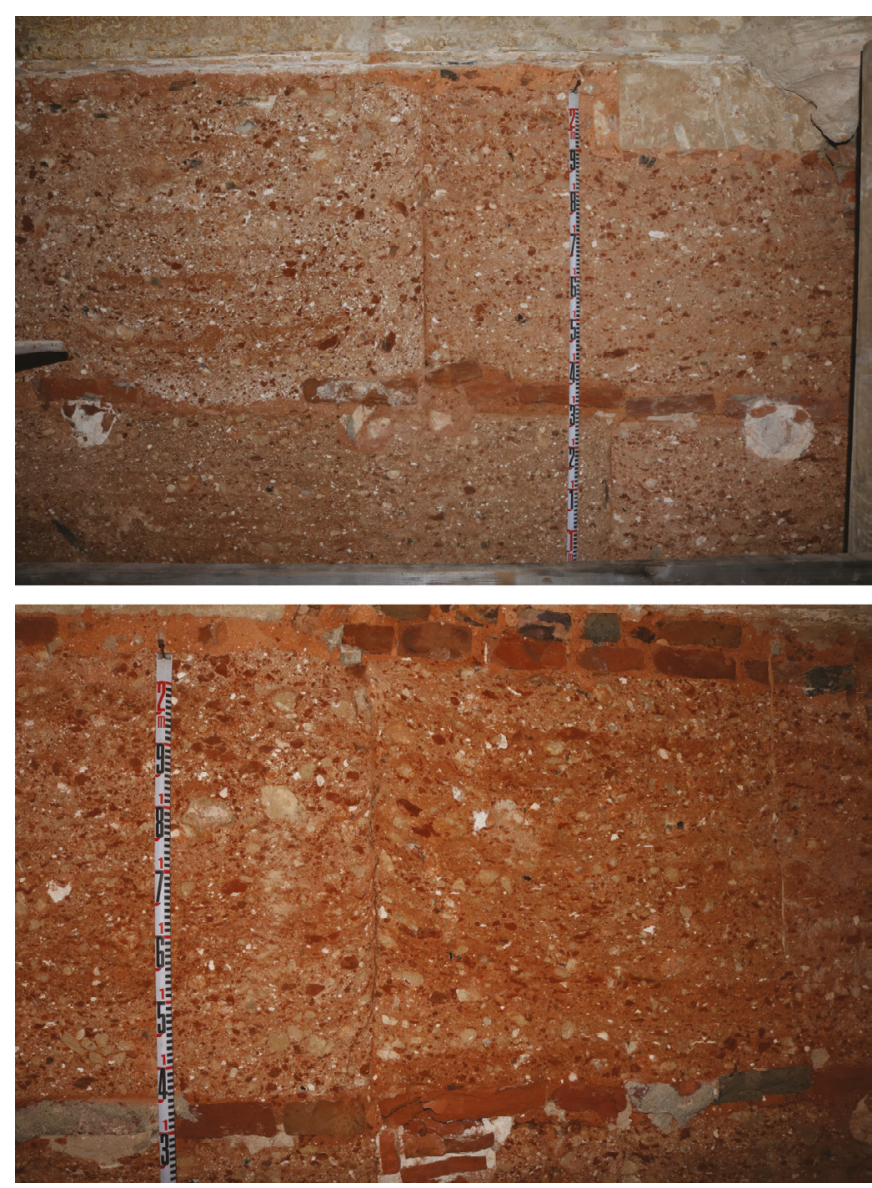

Figura 5. Variantes de tapiería del muro sur del transepto. 
Al igual que la tapiería, la mampostería es otra de las técnicas más utilizadas en la construcción de la Iglesia San José. Se encontraron fábricas de mampostería en todos los paramentos de los muros estudiados -paredes del ábside, transepto, nave central y naves laterales-, en las fábricas de los contrafuertes y cegamientos de algunos tipos de vanos. A diferencia de la tapiería, utilizada exclusivamente en la construcción del polígono original del s. XVI, distintos tipos de mampostería se emplearon en todas las ampliaciones, adiciones y remodelaciones hechas en el edificio a partir del s. XVII. Específicamente, se observaron distintas variaciones de mampostería en la ampliación de la nave central y en la construcción de las capillas de Belén y Rosario.

En el caso de la sillería, esta fue ampliamente utilizada en las construcciones de muchas de las estructu- ras que dieron forma al polígono más antiguo de San José. Principalmente, se implementó para solucionar problemas de tipo estructural con sillares de distintos tamaños que se encuentran reforzando las esquinas del muro sur y este del transepto y rematando los contrafuertes del Salón II.

En San José el exquisito trabajo de sillería quedó plasmado, sobre todo, en la construcción de las cúpulas y bóvedas góticas del s. XVI que cubren los espacios del ábside, crucero y transepto, de la Capilla de San Vicente Ferrer en la nave lateral norte y los salones de la nave lateral sur. Las formas decorativas de las molduras, nervaduras y arcos de las cúpulas y bóvedas góticas se lograron esculpiendo las distintas piezas o sillares una vez colocadas (Fig. 6). En América, estos tipos de cúpulas y bóvedas solo tienen pa-
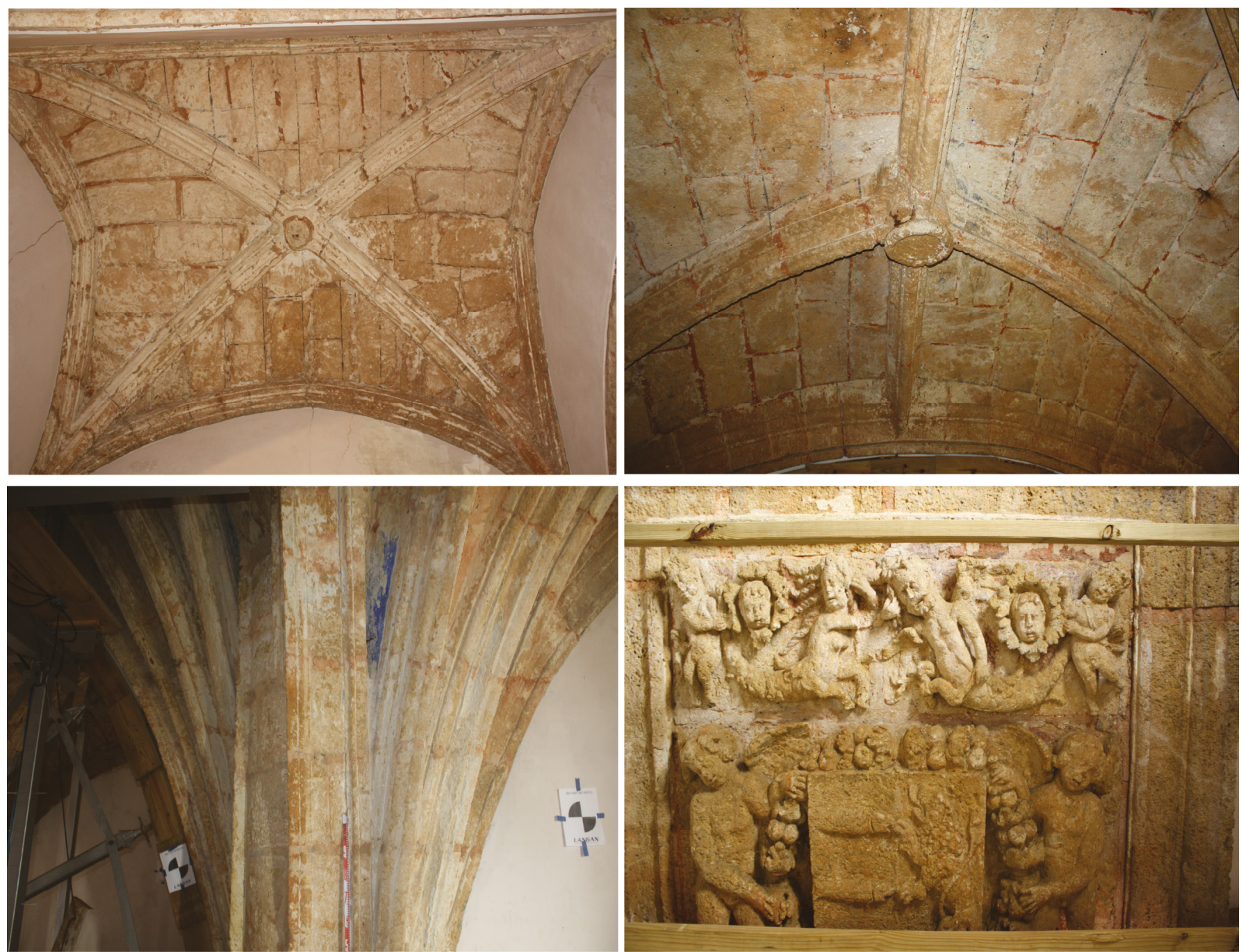

Figura 6. Varios ejemplos de las bóvedas y otros trabajos en sillería: izquierda superior, bóveda nave lateral sur; derecha superior, detalle nervaduras, bóveda transepto; izquierda inferior, detalle nervaduras de la pilastra sureste entre transepto y ábside; derecha inferior, tarja que detalla el escudo de la familia García Troche-Ponce de León. Parte superior muro norte, ábside. 
ralelos en la Catedral de San Juan (Buchiazzo 1955) y la Catedral de Santo Domingo (Flores Saso 2006).

Igualmente, se empleó también sillería en (1) la construcción de las cuatro imponentes columnas que sostienen la gran cúpula del crucero; (2) en los arcos que comunican las naves laterales con la nave mayor; (3) en la construcción de las ventanas abocinadas que se encuentran en las paredes del ábside y transepto que dan hacia la plaza (sur); y (4) para las cornisas que coronan al exterior los muros que forman el polígono original de la iglesia -ábside y transepto-. Posterior a la obra del edificio original, (5) piedras labradas o si1lares fueron utilizados como parte de la construcción de la Capilla de Belén en el arco del vano abierto en la pared sur del transepto.

\section{A. Tipología de fábricas}

En el polígono asociado al s. XVI de San José la mayoría de los muros fueron construidos mediante técnicas mixtas. Con el estudio de fábricas, para las técnicas mixtas se definieron varios tipos de muros basados en su tipología en la Iglesia San José (Figs. 7-8):

\section{Tipo 1. Muros de tapia encadenada en mampostería se-} paradas por verdugadas de ladillos.

Se encuentran en el cuerpo bajo de los muros que forman el ábside (Salón I) y de los muros norte, este y sur del transepto (Salón II). Este tipo de fábrica se caracteriza por alzadas, de entre $85-90 \mathrm{~cm}$ de alto, formadas por cajones de tapias encadenados por mampostería. Regularmente se hallan separados por verdugadas de ladrillos a todo lo largo de los muros. Las verdugadas están formadas por dos o tres hiladas de ladrillos, aparejados de forma regular alternando hileras de ladrillos a tizón y otras puestas a soga. A la altura de las verdugadas se encuentran los mechinales a intervalos más o menos regulares de $55-65 \mathrm{~cm}$.

Este tipo incluyó como elemento distintivo estructuras de vano para ventanas a modo de arcadas de ladrillo con arcos rebajados. Estas arcadas se caracterizaron por localizarse a nivel de la primera alzada en los muros norte y sur del ábside.

El Tipo 1 podemos asociarlo a una variación de los Tipos 9-11 definidos por Graciani García y Tabales Rodríguez como "de fraga, encadenado y verdugado en ladrillo" (2008: 138-139). Este, a diferencia de los identificados en Sevilla, combina sin patrón aparente, más que las necesidades específicas para cada parte de la estructura, verdugadas simples, dobles o triples. La cronología del Tipo 1 identificada para San José corresponde temporalmente con los Tipos 9-11 sevillanos, ubicándolo en pleno s. XVI. Aunque la cronotipología establecida por Graciani García y Tabales Rodríguez identifica una división en periodos para el tapial de verdugada simple (Tipo 9 - periodo mudéjar - 1248-principios s. XVI) con los de verdugada doble y triple (Tipos 10-11 - periodo moderno - ss. XVI-XVIII), resulta evidente que esta tradición constructiva puede rastrearse a Andalucía para este periodo.

\section{Tipo 2. Muros de tapia encadenados en mampostería}

Se encuentran en el cuerpo medio y alto de los muros que forman el ábside (Salón I). Se alzaron sobre los muros Tipo 1 en un evento constructivo posterior, por lo que se explica la diferencia en técnica constructiva. En este tipo de fábrica la mampostería se encuentra encadenando los cajones de tapia dispuestos de forma escalonada, hasta la altura de la pared. Los cajones de tapia, de unos dos metros de largo, por noventa centímetros de alto y hasta un metro de ancho $(2 \times 0,9 \times 1$ $\mathrm{m})$, se encuentran organizados en hileras de entre tres a cinco cajones aparejados alternando juntas entre las hileras. En estos tipos de muros las verdugadas entre la mampostería e hileras de cajones de tapia son esporádicas. Es decir, su arreglo dentro del conjunto de fábricas es irregular. Dado que, casi ninguna cubre el ancho completo de las paredes y normalmente se encuentran colocadas separando los cajones de tapia. En este caso, las verdugadas son todas de una hilera de ladrillos puestos a soga y tizón y aparejados irregularmente.

Este lo podríamos asociar al Tipo 9 según Graciani García y Tabales Rodríguez, cuya irregularidad en la disposición de las verdugadas podría ser una variante que ambos denominaron como "latericia" (2008: 138-139). Estas variantes las vemos incluso en diferentes alzadas del mismo muro.

\section{Tipo 3. Muros de tapia encadenados en mampostería y reforzados con sillares}

Se encuentra en el cuerpo medio y alto de los muros este y sur del transepto (Salón I). Estos muestran la variación en la técnica empleada para la construcción de los muros Tipo 2, aun cuando ambos fueron producto 

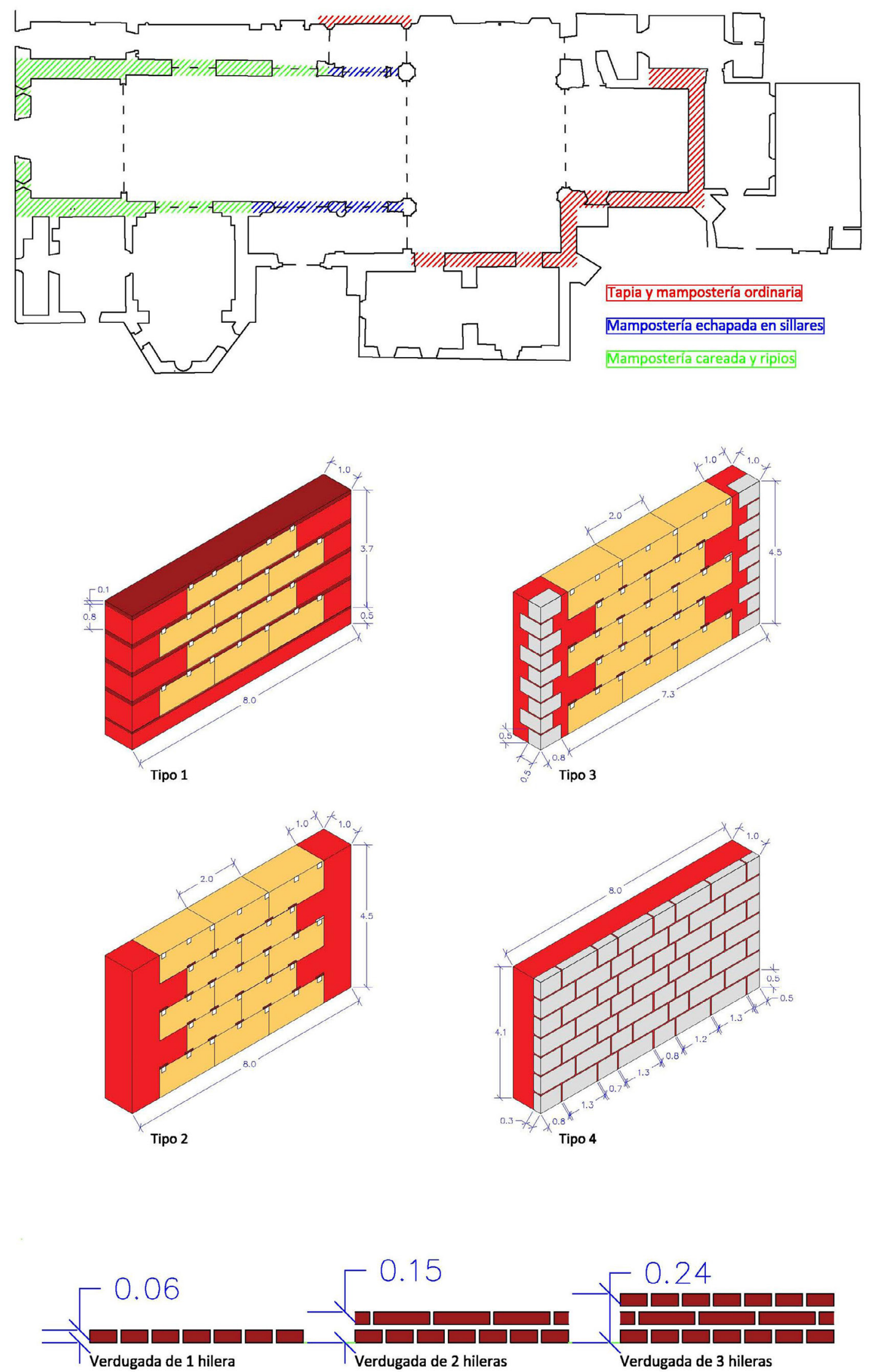

Figura 7. Tipologías de muros y planimetría sobre su localización en planta. 
de un mismo evento constructivo. Este tipo de fábrica tiene las mismas características que las descritas para los muros Tipo 2. La diferencia estriba en que las esquinas de estos muros son reforzadas por sillares de diferentes tamaños y dispuestos alternando las juntas. Esta variación posiblemente respondió a una necesidad mecánica de los muros en el cuerpo alto de estar reforzados con sillares para poder sostener la carga de las bóvedas de sillería.

\section{Tipo 4. Muros de mampostería ordinaria enchapada con sillares}

Se encuentran en el tercio oriental de los muros que delimitan al norte y sur la nave central (Salón III). Este tipo de fábrica está construida en mampostería ordinaria y enchapado con sillares; se observa en el paramento que da hacia el interior de la nave mayor (Salón III). Estos sillares varían en tamaño entre unos $70 \mathrm{~cm}$ a $1,3 \mathrm{~m}$ de largo, por $50 \mathrm{~cm}$ de alto promedio y un estimado de 25 $\mathrm{cm}$ de grosor. Los sillares del enchapado se encuentran dispuestos alternando las juntas y posiblemente respondió a un aspecto puramente estético de crear la impresión de que toda la iglesia estaba construida en sillería.

Otras técnicas constructivas definidas para la Iglesia San José asociadas a etapas constructivas posteriores:

\section{Tipo 5. Muros de mampostería ordinaria}

Esta fábrica se documentó en el alzado del muro que comparte la iglesia con el convento. La mampostería
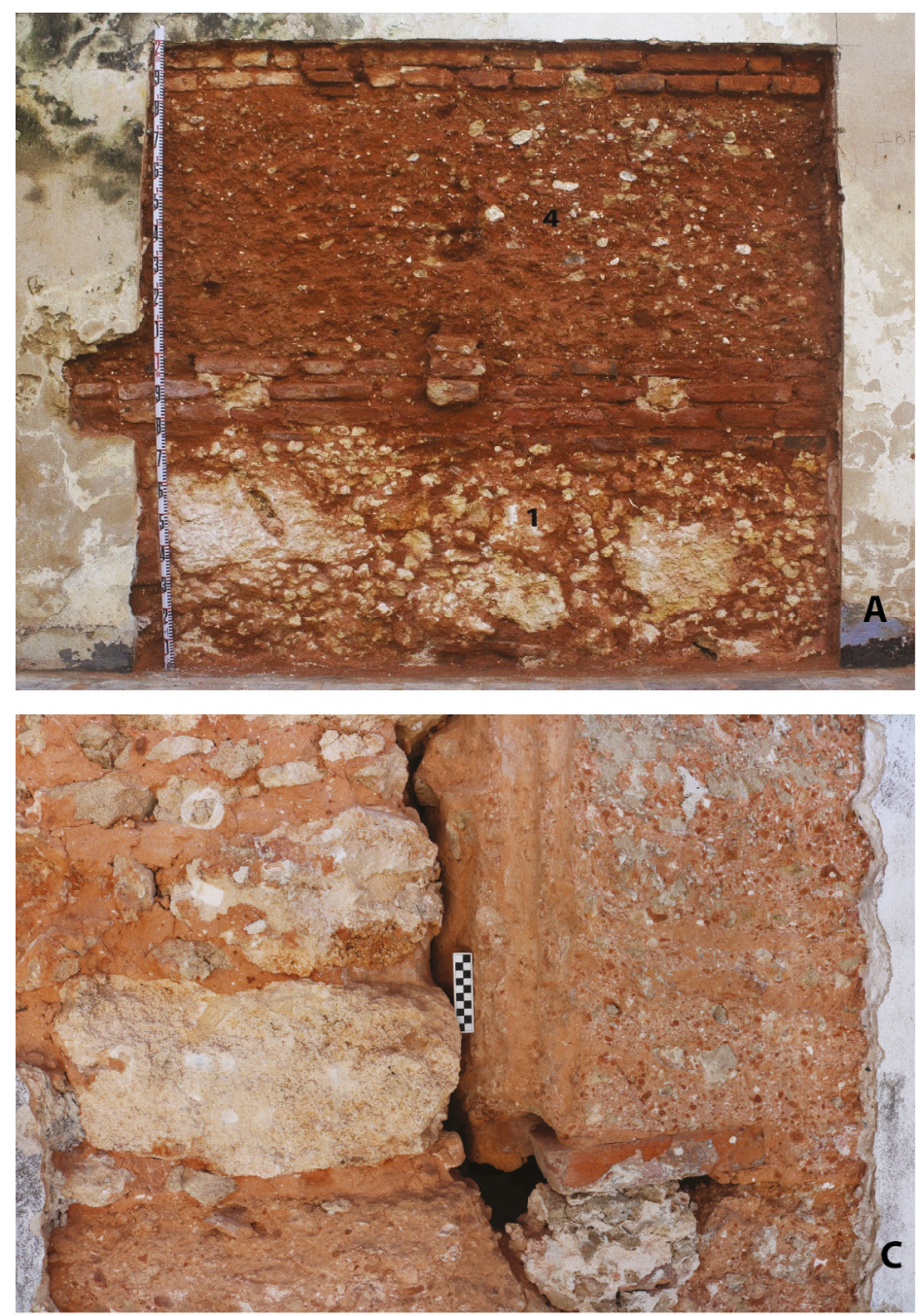
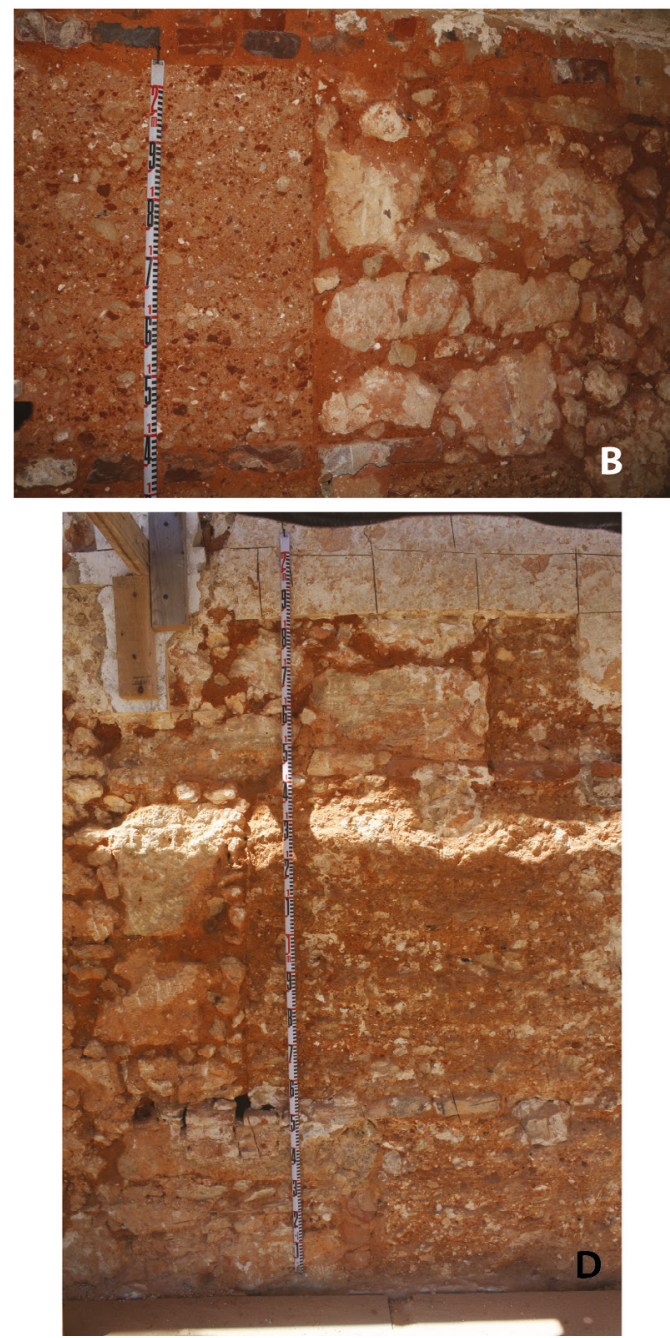

Figura 8. Tipologías de muros identificados en el polígono del s. XVI; A: Tipo 1, tapia encadenada en mampostería con verdugadas (muro este, ábside); B: Tipo 3, tapia encadenada en mampostería y reforzada con sillares (muro sur, transepto); C: Tipo 2, tapia encadenada en mampostería con grieta en la juna entre ambas fábricas (muro este, ábside); D: Tipo 3, tapia encadenada en mampostería y reforzada con sillares (muro exterior sur, transepto). 
ordinaria se asocia con el polígono original del convento de los dominicos y cuya esquina sureste se observa en la Capilla de San Vicente Ferrer. Sobre esta esquina se adosaron los muros Tipo 1 y 2 pertenecientes al transepto. Esta técnica también se identificó en la Capilla del Rosario en varias cimentaciones que asociamos a la iglesia del s. XVI debido a que estaban bajo el relleno que compone el piso de esta, aunque no se pudo determinar su función específica. Estos remanentes, además, están alineados con el muro de la entrada sur de la iglesia que da acceso desde la Plaza San José. Además, se identificaron muros de mampostería ordinaria en el salón este de la Capilla de Belén. Todas ellas, con funciones estructurales similares, se diferencian en el tamaño de los mampuestos y las dosificaciones en los componentes de los morteros, las cuales responden lógicamente al hecho de haber sido levantadas en épocas diferentes.

\section{Tipo 6. Mampostería careada con ripios}

Este tipo de mampostería se documentó en los muros de carga que conforman la nave central incluyendo la fachada oeste de la iglesia y la segunda planta donde se ubica el coro. Esta fábrica se caracterizó por mampuestos areniscos careados de gran tamaño (que sobrepasan $\operatorname{los} 30 \times 30 \mathrm{~cm}$ ) aparejados de forma más o menos regular donde en ocasiones los ripios están delimitados por lajas de arenisca. Este tipo de fábrica resultó ser característica de la etapa constructiva de expansión de la nave central durante el s. XVII. Esta técnica no se empleó en ninguna otra estructura de la iglesia.

La mampostería careada con ripios fue una técnica usada con frecuencia por los ingenieros militares del ejército español a partir del s. XVII, y que se prolongó a lo largo de los ss. XVIII y XIX. Se ha podido asociar esta técnica a varias obras en las que está constatada
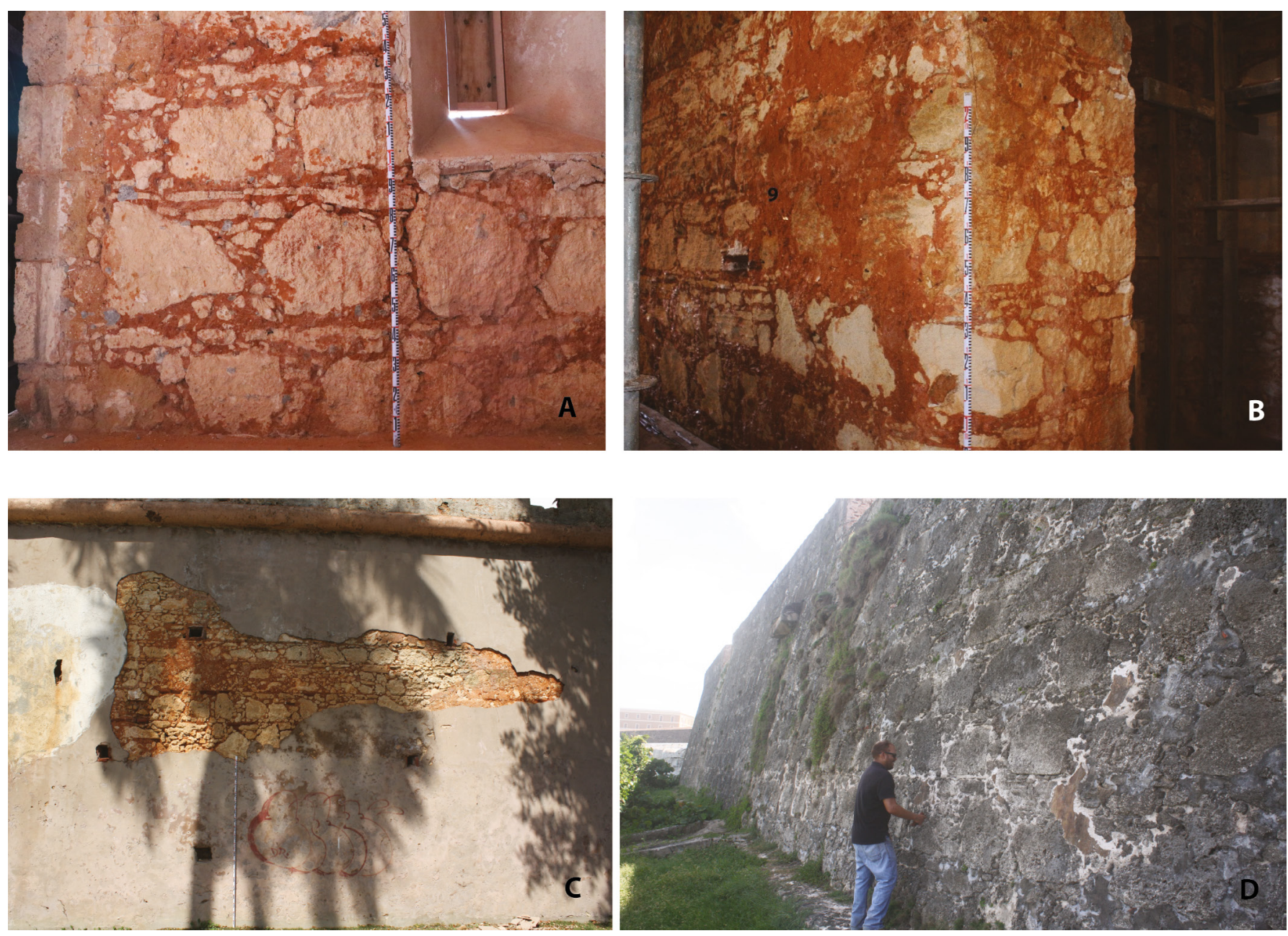

Figura 9. Variedades de mampostería careada con ripios; A: muro oeste nave central; B: esquina muro norte nave central (ca 1641); C: muro de contención, Jardines Occidentales, Casa Blanca (1841-45); D: variación en sillarejo concertado, Bastión de Ochoa, San Felipe del Morro (ca 1650). 

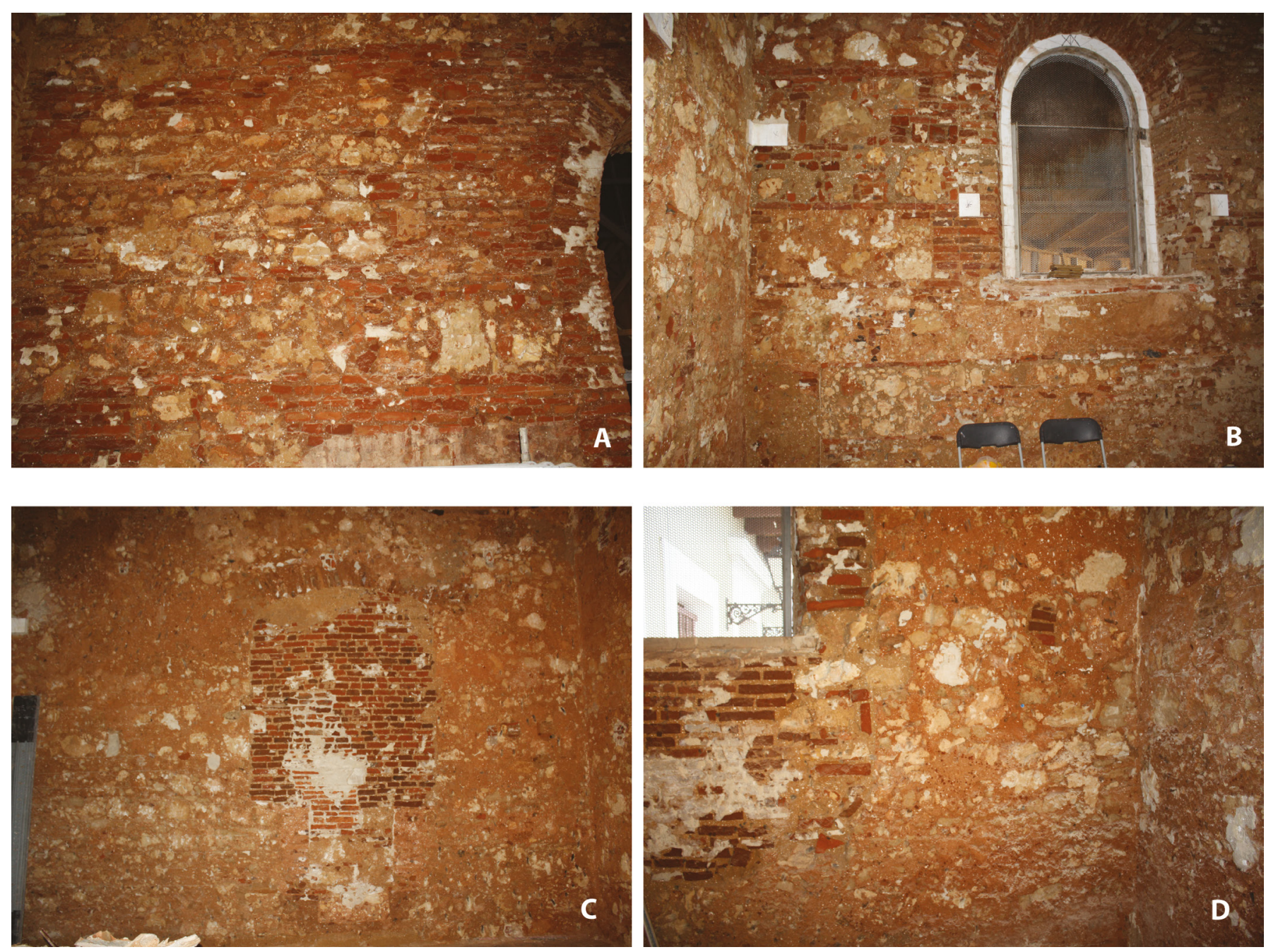

Figura 10. Muros de la Capilla de Belén; A-B: fábrica de mampostería encadenada en ladrillos con verdugadas (salón oeste, ca. 1858-63); C-D: mampostería ordinaria (salón este, ca. 1635-41).

la participación de ingenieros militares: la ampliación del crucero en la Iglesia San José entre 1635-1641 y en la construcción de la muralla de contención de los jardines occidentales en Casa Blanca entre 18411845. Además, se han documentado técnicas análogas utilizadas por los ingenieros militares para estructuras masivas, como el sillarejo concertado, empleadas en las ampliaciones de San Felipe del Morro y otras fortificaciones de la ciudad entre 1650-1792 (Fig. 9).

La ampliación del crucero de la Iglesia San José fue costeada por el gobernador general Înigo de la Mota y Sarmiento con fondos asignados al ejército. Así lo constató Diego Torres Vargas en su Descripción de la Isla y Ciudad de Puerto Rico de 1647:

... que el año de [1]641 se hizo, á solicitud de D. Iñigo de la Mota y Sarmiento, gobernador de esta ciudad, como también la mitad del convento de Santo Thomás de Aquino, del orden de Santo Domingo, a expensas de la infantería del presidio, con precepto de capilla y entierro suyo. ${ }^{5}$

Esta cita hace referencia al convento de Santo Tomás de Aquino adjunto a la Iglesia San José y las fuentes históricas en ocasiones hacen referencia al convento para referirse a ambas edificaciones. El comentario de que fue "la mitad" recoge claramente la expansión hacia el oeste del crucero levantado durante el s. XVI.

\footnotetext{
Caro Costas, A. 1989: "Descripción de la Isla y Ciudad de Puerto Rico y de su vecindad y poblaciones, presidio, gobernadores y obispos, frutos y minerales" [1647], Editora, Antología de lecturas de historia de Puerto Rico, p. 337. Editora Corripio, Santo Domingo.
} 

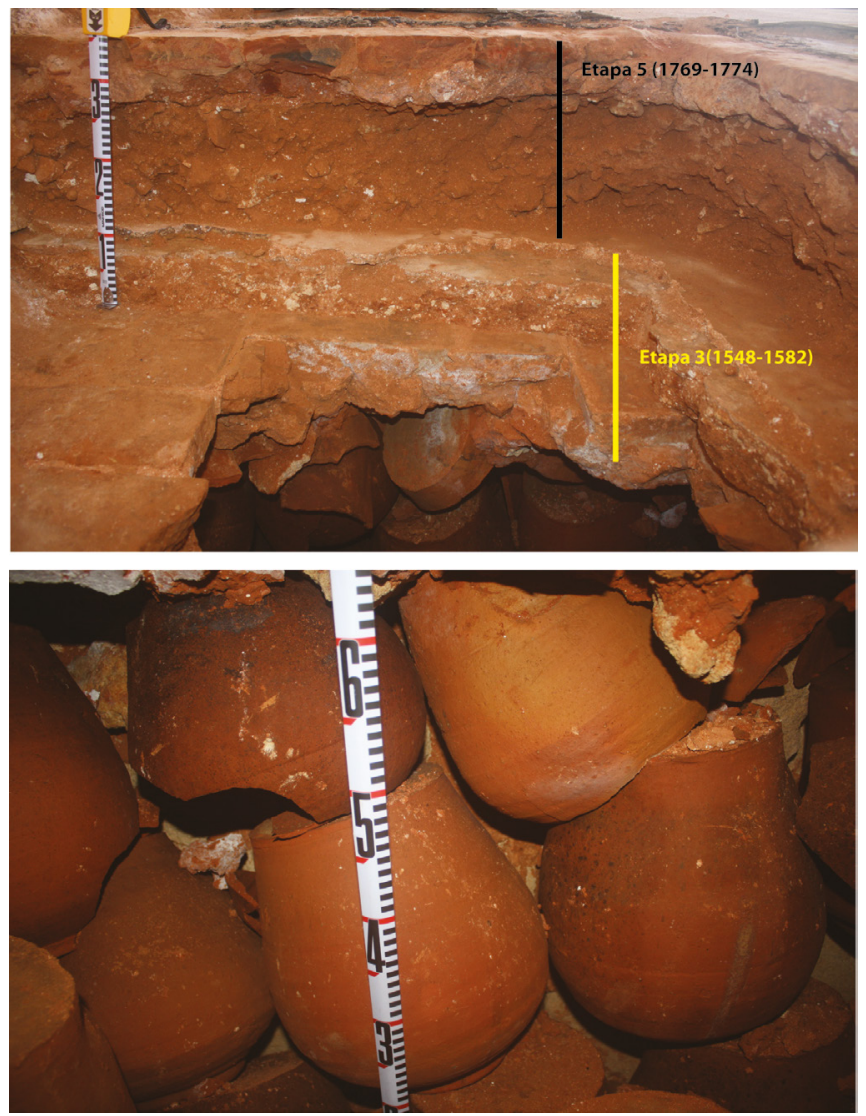

Figura 11. Arriba: vista de las secuencias constructivas para la bóveda de la Capilla de San Vicente de Ferrer, cubierta de ladrillos y su relleno de tinajas asociado a la Etapa 3 y sobre esta, cubierta con relleno granular asociado a la Etapa 5. Abajo: detalle de relleno de tinajas.

De la Mota y Sarmiento fue el gestor de la construcción de otras grandes obras de ingeniería durante su gobernación, entre ellas la más destacada, el amurallamiento de la sección suroeste de la ciudad de Puerto Rico, así como el crucero de la catedral. Según Torres Vargas: "Siguió con tanto afecto la fábrica de las murallas que en los seis años que gobernó acabó la cerca con tres puertas excelentes... Y el crucero de la Iglesia Catedral lo hizo de nuevo porque temía alguna desgracia con su ruina, y hizo una cerca a la iglesia". ${ }^{6}$

\section{Tipo 7. Mampostería ordinaria con verdugadas y enca- denada en ladrillos}

Esta técnica mixta se documentó solamente en el salón oeste de la Capilla de Belén. La misma se caracterizó

${ }^{6} \quad$ Ibid., p. 352.
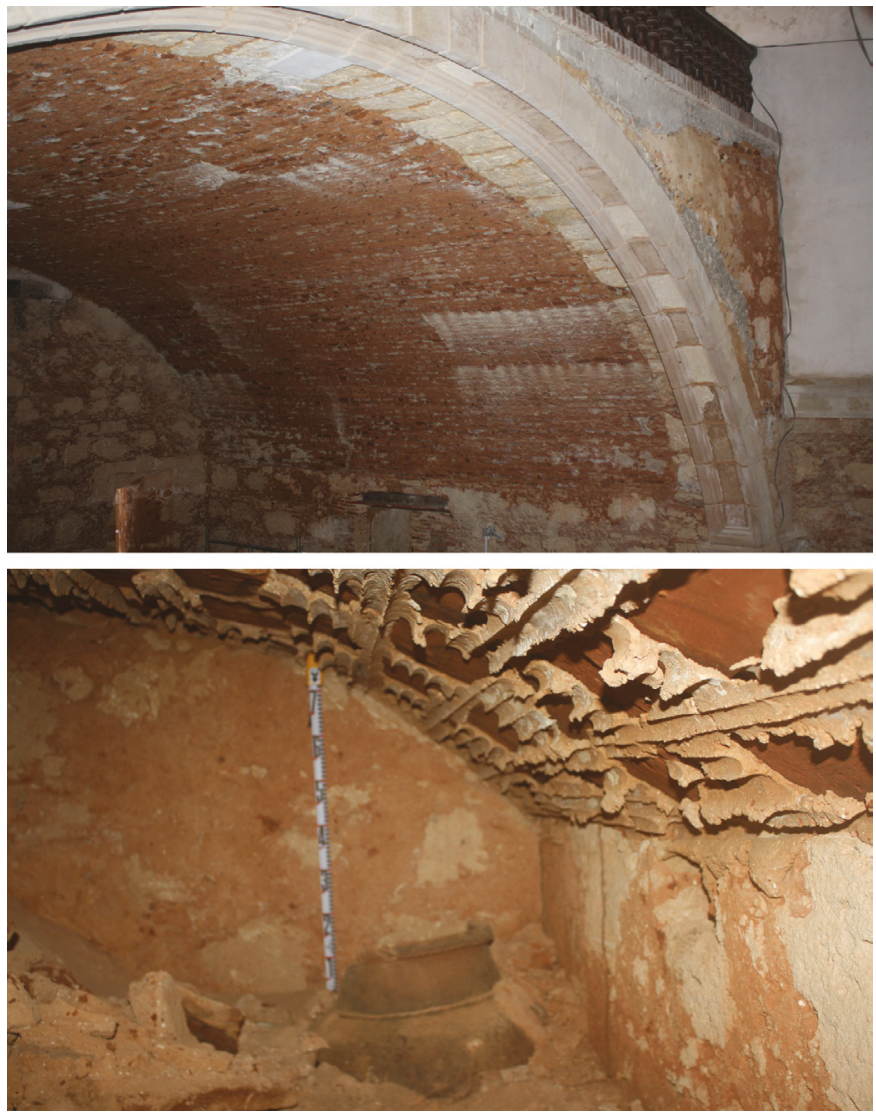

Figura 12. Arriba: vista del arco para el coro, construido en ladrillos rematado con sillarejos. Abajo: detalle de técnica para sujetar la cubierta superior con mortero y cañas colocadas transversalmente. En el fondo, tinaja utilizada como parte del relleno para la bóveda. Etapa 5 .

por cajones hechos en ladrillos aparejados a soga y tizón reforzados principalmente en los vanos de ventanas y puertas. La mampostería ordinaria está separada por verdugadas de ladrillos aparejadas a soga y dispuestas sin patrón aparente, ya que en ciertas partes de un mismo muro se colocaron verdugadas dobles y triples. La mampostería sí guarda cierta regularidad en cuanto a la medida de la alzada promediando $10550 \mathrm{~cm}$ de alto. Estas fábricas están trabadas con un mortero pardo oscuro con abundantes nódulos de cal, el cual se diferencia notablemente del mortero rojizo empleado en la fábrica del salón este de la Capilla de Belén (Fig. 10).

\section{Tipo 8. Estructuras en ladrillo}

Considerando la monumentalidad de las dimensiones y la majestuosidad de las estructuras que componen la Iglesia San José la utilización del ladrillo estuvo limitada a elementos específicos como arcos, vanos y jambas. También fue empleado en cegamientos de puertas y ven- 
tanas. Sin embargo, entre las estructuras construidas en ladrillo destacan la bóveda del coro en el crucero, bóveda de medio punto en el salón oeste y la bóveda octogonal en el salón este, ambas en la Capilla de Belén.

Cabe destacar las variaciones en las técnicas para el levantamiento de estos arcos de medio punto entre los ss. XVI y XVIII. Aunque para ambos periodos se utilizaron recipientes cerámicos como método de alivianar las bóvedas, para las asociadas a la iglesia gótica del s. XVI se utilizaron tinajas expresamente fabricadas para ese propósito adheridas al tope de la bóveda con mortero (Fig. 11). Mientras que para las asociadas al s. XVIII, y en particular la bóveda del coro, se utilizaron orzas y otros recipientes de gran tamaño combinados con un método de sujeción de la cubierta que consistía en un "armazón" de cañas adheridos con mortero. Entendemos que este método fue empleado no para efectos estructurales, sino más bien, como apoyo para sostener dicha estructura hasta el secado del mortero (Fig. 12).

\section{DISCUSIÓN SOBRE SU DESARROLLO CONSTRUCTIVO. ETAPAS CONSTRUC- TIVAS DEFINIDAS PARA SAN JOSÉ}

Como mencionáramos anteriormente, el estudio secuencial y análisis estratigráfico para San José se concentró en el componente asociado al s. XVI: ábside, crucero y transepto. Fue a partir de las secuencias identificadas y definidas en estos componentes que se pudo elaborar el esquema de desarrollo constructivo para todo el inmueble.

La secuencia estratigráfica del ábside resultaba fundamental para entender el proceso constructivo de la iglesia del s. XVI, así como su relación secuencial con el transepto y el convento. En el ábside se identificaron procesos constructivos y de reparaciones enmarcados dentro de cuatro eventos principales. El primer y segundo evento se caracterizaron por la construcción de la Iglesia de Santo Tomás de Aquino con sus bóvedas góticas. El tercer evento se relacionó con cegamientos y aperturas de ventanas. Por último, el cuarto evento consistió en las obras de construcción de la sacristía, así como intervenciones en varias áreas relacionadas con reparaciones. Estos cuatro eventos constructivos agruparon un total de 47 UEM (Véase Anexo, pestaña Ábside).

Del análisis estratigráfico se desprende que el transepto fue el resultado de seis grandes eventos constructivos que le dieron la forma actual, y posteriormente, pasó por diversos eventos de reparaciones, aperturas y cegamientos de vanos y aperturas de nichos. El primer y segundo evento se caracterizaron por la construcción de la Iglesia de Santo Tomás de Aquino con sus bóvedas góticas. El tercer evento fue la construcción de los arcos de sillería en las capillas laterales, al norte y sur de la nave central. El cuarto evento fue la construcción de la Capilla de Belén. El quinto evento fue una serie de aperturas $\mathrm{y}$ cegamientos de nichos $\mathrm{u}$ hornacinas en varias áreas del transepto. Por último, el sexto evento consistió en la apertura de varios nichos y su posterior cegamiento en materiales contemporáneos como el cemento Portland y bloques. Estos seis eventos constructivos agruparon un total de 53 UEM (Véase Anexo, pestaña Transepto).

En la nave central, por su carácter de espacio de transición entre la iglesia del s. XVI y las ampliaciones posteriores, se evidenciaron grandes eventos constructivos que modificaron considerablemente la fisonomía del inmueble. De la misma forma se documentaron obras de reparaciones de menor escala. Estos procesos constructivos se enmarcan en cinco eventos. El primer evento se caracterizó por la construcción de la Iglesia de Santo Tomás de Aquino con sus bóvedas góticas. La fachada oeste de la nave central evidenció que existió un techado de madera, posiblemente a dos aguas adosado a los muros del transepto. El segundo evento se relacionó con la construcción de la sección oeste de la nave central. El tercer evento consistió en las obras de construcción de la Capilla del Rosario. El cuarto evento consistió en el levantamiento de muros de carga que sostienen la bóveda de medio cañón y sus estructuras relacionadas. Por último, se documentó un quinto evento relacionado con reparaciones menores con materiales contemporáneos, como el cemento. Estos cinco eventos constructivos agruparon un total de 38 UEM (Véase Anexo, pestaña Nave central).

El salón que ocupa la nave lateral norte, donde actualmente se encuentra la Capilla de San Vicente Ferrer, está compuesto de estructuras de arcos que descansan sobre pilastras de sillería. El análisis estratigráfico de este salón tuvo una importancia fundamental por ser parte del convento, su estratigrafía permitió comprender la relación secuencial con la iglesia y su bóveda gótica.

Este evidenció unidades estratigráficas murarias asociadas a tres eventos constructivos de gran envergadura. El primero, relacionado a la construcción del convento, en particular la esquina sureste. El segundo evento se relacionó con la construcción de la iglesia gótica y sus naves laterales, en este caso la norte, donde se encuentran bóvedas góticas de menor dimensión. El tercero, es- 
tuvo dirigido a reparaciones de carácter estructural con la reparación de los arcos góticos de la capilla. Mientras que eventos posteriores fueron el producto de aperturas de estructuras de vanos, cegamientos, cortes de fábricas para nichos y otras reparaciones contemporáneas. Estos tres eventos constructivos agruparon un total de 30 UEM (Véase Anexo, pestaña Nave lateral norte).

Basado en estudio de fábricas para cada salón, sus secuencias estratigráficas y sus relaciones secuenciales, se definieron siete (7) etapas constructivas para el conjunto de estructuras que componen la Iglesia San José. A su vez, estas etapas se relacionan con periodos históricos específicos a partir de la documentación histórica y cartográfica (Fig. 13).

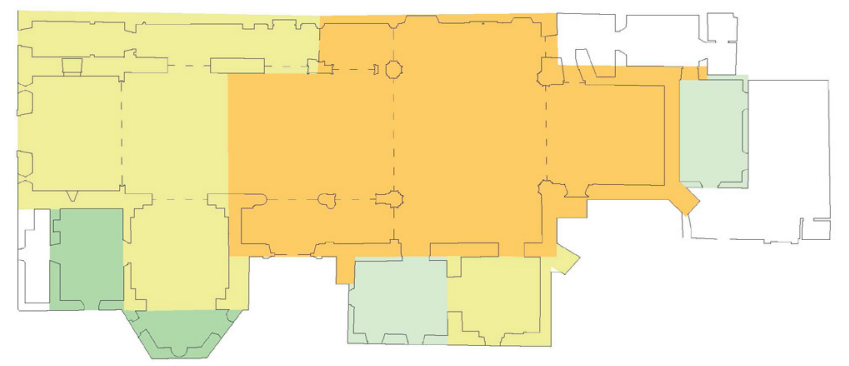

Etapa II-III, ca. 1530-1582

Etapa V, ca. 1769-1774

Etapa IV, ca. $1635-1641$

Etapa VI, ca. 1858-1863

Figura 13. Esquema de etapas constructivas a partir del estudio de fábricas y secuencias estratigráficas.

\section{A. Etapa 1 (ca. 1523-1530): Convento de Santo Domingo}

Esta etapa inició la construcción del polígono primigenio del convento de Santo Domingo adjunto a lo que posteriormente fue la Iglesia San José. La fundación de la comunidad dominica en la isla estuvo a cargo de fray Antonio Montesinos, y las obras comenzaron en 1523 contando con una asignación de 50.000 maravedíes mediante cédula real el año anterior:

Por parte de los frayles dominicos que resyden en estas partes me hes hecha rrelacion que ellos haczen en la cibdad de Puerto Rico desa isla un monasterio y casa de su orden suplicaronme para ayudar dello les hiziese alguna merced por ende yo vos mando que de qualesquier maravedís e oro de vuestro cargo de las dichas penas deys e paguéis a los dichos frayles cincuenta mil maravedís de que yo les hago merced para ayudar a hazer la dicha casa para que los gasten en lo susodicho.?

Estos fondos nunca fueron asignados por los oficiales reales. Ante la falta de fondos para dar continuidad a las obras de construcción, en 1524 el rey promulga una nueva cédula en respuesta al pedido de Montesinos para que los oficiales reales cumplieran la misma asignando 4.000 pesos por los próximos ocho años "por bien e por la presente hago merced e limosna a la dicha orden para ayudar a la obra del dicho monasterio e iglesia de quatro mill pesos de oro para que se den e paguen en ocho años quinientos pesos cada año". ${ }^{8}$

La evidencia arqueológica y documental permiten comprobar que con esta asignación se garantizó la culminación de la construcción del convento, quedando pendiente la iglesia. El convento se construyó en una fábrica de mampostería ordinaria que incluyó vanos de puertas abocinado; y jambas hechas en ladrillos. El muro de carga sur del convento, que luego sirvió de muro medianero entre ambas estructuras, principalmente su esquina sureste, se convirtió en la base para la construcción de la Iglesia de Santo Tomás de Aquino. Durante este evento, esta sección del muro era un área de paso entre el convento y el exterior (Fig. 14).

\section{B. Etapa 2 (ca. 1532-1535): inicios de la Iglesia de Santo Tomás de Aquino}

Durante esta etapa se construye la primera alzada de la Iglesia de Santo Tomás de Aquino, probablemente entre 1532 y 1535. Su construcción abarcó el cuerpo bajo de los muros de carga partiendo con su adosamiento desde la esquina sureste del convento, tanto del ábside como del transepto. Esta primera alzada, de aproximadamente 3,95 metros de altura, se caracterizó por muros Tipo 1, es decir, con zapata hecha en mampostería ordinaria y sobrepuesta por una fábrica hecha en técnica mixta de tapia encadenada con mampostería ordinaria y verduga-

\footnotetext{
Alegría Gallardo, R. 2009: "Real cédula a los oficiales de la isla de San Juan ordenando pagar a los frailes dominicos cincuenta mil maravedíes para la construcción de un monasterio" [1522], Editor, Documentos históricos de Puerto Rico, Volumen II. Pp. 379. Centro de Estudios Avanzados de Puerto Rico y el Caribe. San Juan.

8 Ibid.: "Real cédula a los oficiales de la isla de San Juan mandando que paguen a los frailes dominicos quinientos pesos anuales hasta llegar a un total de cuatro mil pesos para la construcción de un monasterio" [1524], Volumen II, pp. 443-444.
} 


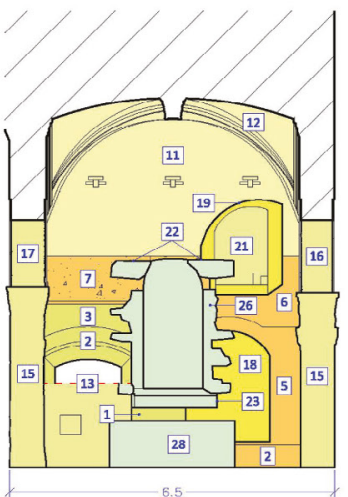

Pared Norte

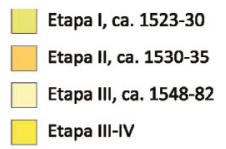

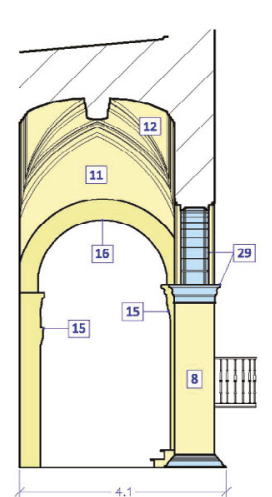

Pared Este

Etapa IV, ca. 1635-41

Etapa V, ca. 1769-74

Etapa VI, ca. 1858-63

post. 1930

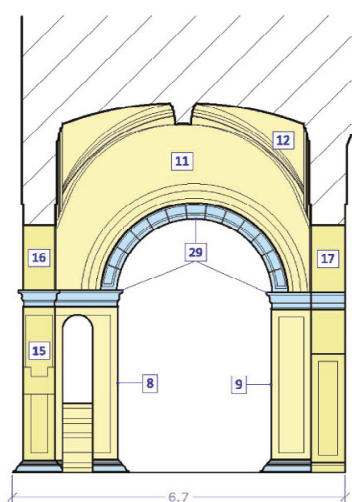

Pared Sur

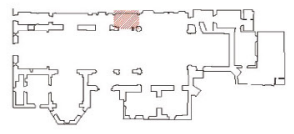

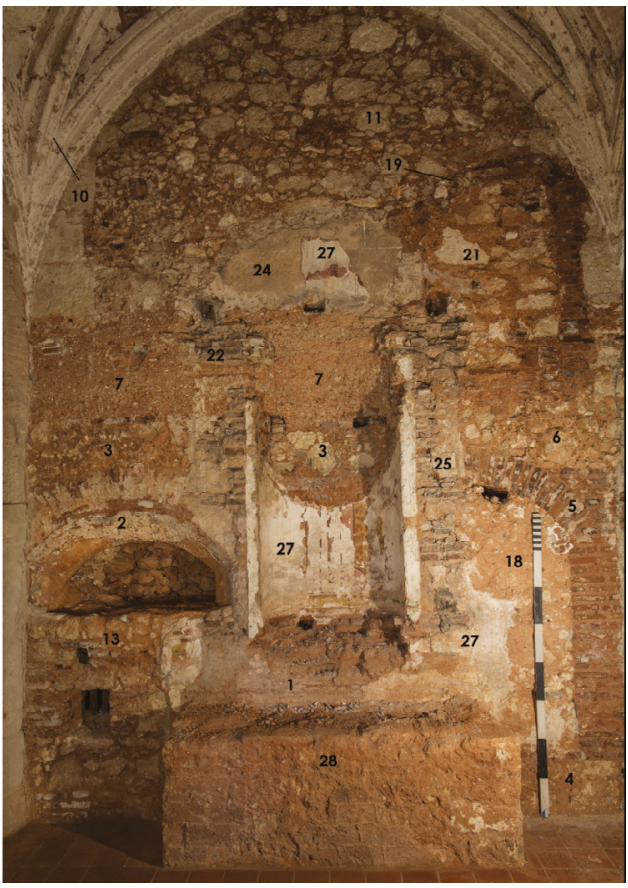

Figura 14. Alzada norte del paramento interior de la nave lateral norte (San Vicente Ferrer). En verde olivo las fábricas asociadas al convento de los dominicos; en anaranjado las fábricas que corresponden a la primera alzada; en amarillo fábricas de la segunda alzada y el resto de las modificaciones posteriores. Foto: Alberto Rigau.

das de ladrillos. La construcción de esta primera alzada incluyó el muro sur (ábside y transepto), arcos rebajados y gruesas pilastras de ladrillo a modo de arcadas rematadas por contrafuertes. En el ábside se hicieron dos ventanas cercanas a su adosamiento con el transepto, mientras que en el transepto se hicieron dos vanos de puerta en sus extremos y una ventana en el medio. En el muro este del ábside se construyó una ventana con arco rebajado y jambas de ladrillo (Salón III).

Durante esta etapa, la primera alzada abarcó exclusivamente el polígono del transepto y ábside hasta el área donde se adosa a la nave central. Se construyeron los contrafuertes noreste y sureste del ábside, en la misma técnica de tapia encadenada en mampostería ordinaria con verdugadas de ladrillo, como extensiones de los muros de carga norte, este y sur.

La iglesia estuvo sin actividad constructiva por falta de fondos entre 1535 y 1548. Para esta fecha todavía no se habían entregado los 50.000 maravedíes asignados en 1522, aparentemente ante la negativa de los oficiales reales. No es hasta 1535 cuando la corona finalmente asigna los fondos para iniciar su construcción:

E agora por parte del prior frayles y convento del dicho monasterio me ha sido hecha rrelacion que los maravedís contenidos en la dicha cedula [1522] suso encorporada hasta agora no les avian sido dados ni pagados ni parte alguna dellos como dixeron constava y parecía por ciertos testimonios de que ante nos en nuestro consejo de las Yndias fue fecha presentación e me fue suplicado que pues la dicha merced avia sido para la obra y edificio del dicho monasterio toviese por biende se los mandar pagar conforme a ella o como la mi merced fuese por ende yo vos mando que veays la dicha cedula. ${ }^{9}$

\section{Etapa 3 (ca. 1548-1582): culminación de la iglesia gótica}

Esta etapa abarcó las obras de mayor amplitud que le dieron la fisonomía gótica isabelina característica del s. XVI. Tal parece que las obras de construcción comenzaron a finales de 1548 ya que en septiembre de ese año el obispo de la ciudad, Rodrigo de Bastidas, todavía solicitaba al rey para que obligase a la orden

\footnotetext{
9 Ibid: "Real cédula a los oficiales de la isla de San Juan reiterando el pago de cincuenta mil maravedíes a los frailes dominicos para la construcción de monasterio de Santo Domingo" [1535], Volumen III. Pp. 511-512.
} 
que dispusiera de parte de su patrimonio en granjas y ganado, así como fondos adicionales para completar la iglesia

...ellos tienen por acabar su iglesia y la casa como es grande sustentase con trabajo su edificio si su V.M. fuere servido seria justo me parece que mandase a estos religiosos que viviesen debaxo de la observancia y pobreza con que poblaran y dispusiesen y vendiesen estos ganados y haciendas que tienen y con lo procedido de ello acabasen su iglesia y convento y faltándoles V.M. los favores rescaese con su real limosna escribo esto que es lo que desta cosa siento y porque me han hablado de cierta probanza que han hecho en este pueblo para enviar a V.M. suplicandole les ayude para la dicha edificación de su convento. ${ }^{10}$

Las obras comenzaron con la construcción de los muros de carga sur y oeste de la nave lateral sur, y las cuatro pilastras de sillería que sostienen las bóvedas de ambas naves laterales y del crucero. En el caso de la nave lateral sur, su muro sur se construyó adosado a la fábrica de la primera alzada como continuación del muro del transepto hacia el oeste. La nave lateral norte se levantó sobre los muros del convento y la primera alzada. La fábrica de la nave lateral se caracteriza por la mampostería encadenada en sillares que sostiene sus bóvedas, formando también el resto del muro de carga del transepto.

A la misma vez se fueron levantando los contrafuertes suroeste del ábside y sur de la nave lateral sur desde el nivel de suelo. Los mismos fueron hechos en una fábrica de mampostería ordinaria encadenada en sillares y levantados hasta nivel de la segunda alzada. En el caso del contrafuerte, se abrió un vano de ventana en los sillares que encadenan la mampostería (Fig. 15).

También se construyeron los muros Tipo 4 en el norte y sur de la nave central, los cuales cierran a la misma vez las naves laterales. Estos fueron hechos en una fábrica de mampostería enchapada con sillares, levantados sobre pilastras de sillería que conformaban dos arcadas que sirven de acceso a ambas desde la nave central. Aquí se evidenció su continuidad hasta

\footnotetext{
10 Ibid: "Carta del obispo Rodrigo de Bastidas al rey sobre la situación económica, la construcción de un templo ante el deterioro del existente.” [1548], Volumen IV. Pp. 43-45.
}
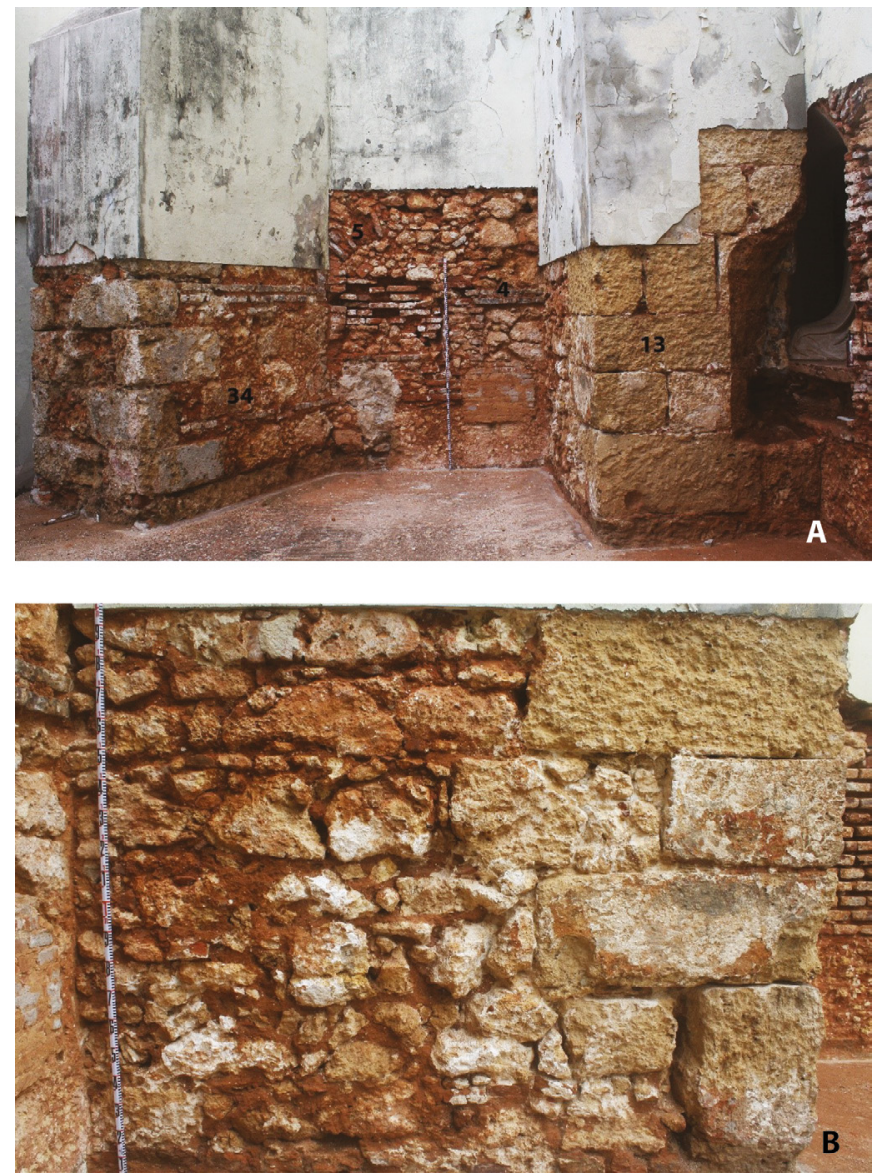

Figura 15. A: paramento exterior del este del transepto con el contrafuerte UEM 13 asociado a la iglesia gótica, y el UEM 34 asociado a la construcción de la capilla de Belén. B: fábrica de mampostería encadenada con sillares, primera alzada del contrafuerte UEM 13.

los muros que cierran el lado este de la capilla del Rosario, incluyendo el vano de puerta hecho en sillería. Otro aspecto que ubica el muro sur dentro de esta etapa es la bóveda gótica que cubre esta sección cuyo espacio interior sirve de vestíbulo para la entrada sur y área de paso hacia la nave central. Tal y como muestra la cartografía y otras ilustraciones, su techado estuvo construido en madera y levantado a dos aguas (Fig. 16).

Paralelamente, se fueron levantando las pilastras de sillería que sostienen las nervaduras, los muros frontales de mampostería y sillares y la bóveda. En el caso de su bóveda gótica hecha en sillería, como el resto de las bóvedas asociadas a este evento, se caracterizaron por estar rellenas con tinajas como forma de alivianar su peso en relación con la cubierta superior. Durante este evento esta constituyó un área de paso como acceso entre el convento y la iglesia gótica (Fig. 17). 

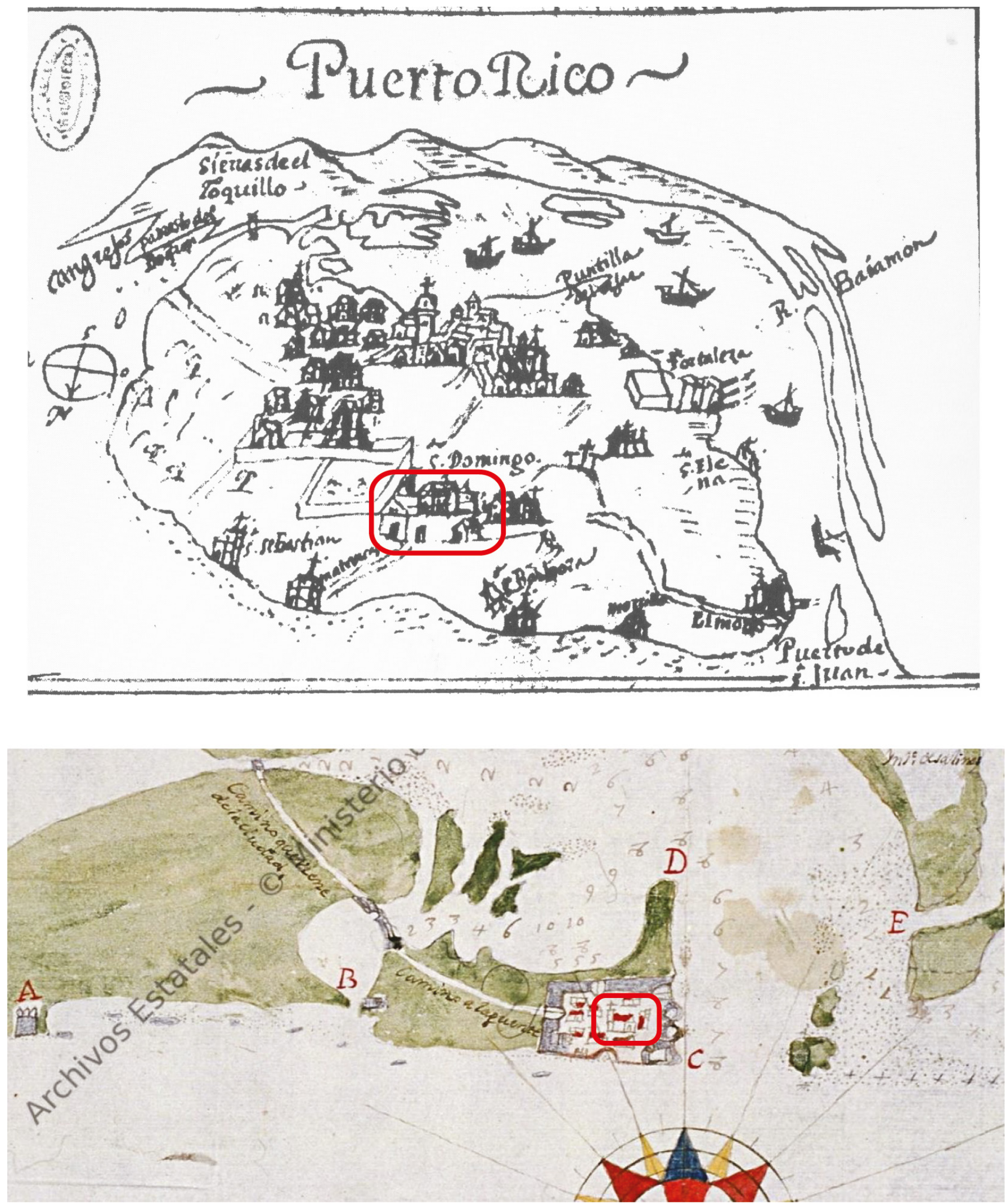

Figura 16. Arriba, San Juan 1575, dibujado por Juan Escalante de Mendoza. Reproducido por Murga Sanz 1960. Abajo, San Juan, 1660. Detalle de plano preparado por Francisco Pisente Duran. AGI, Santo Domingo. 


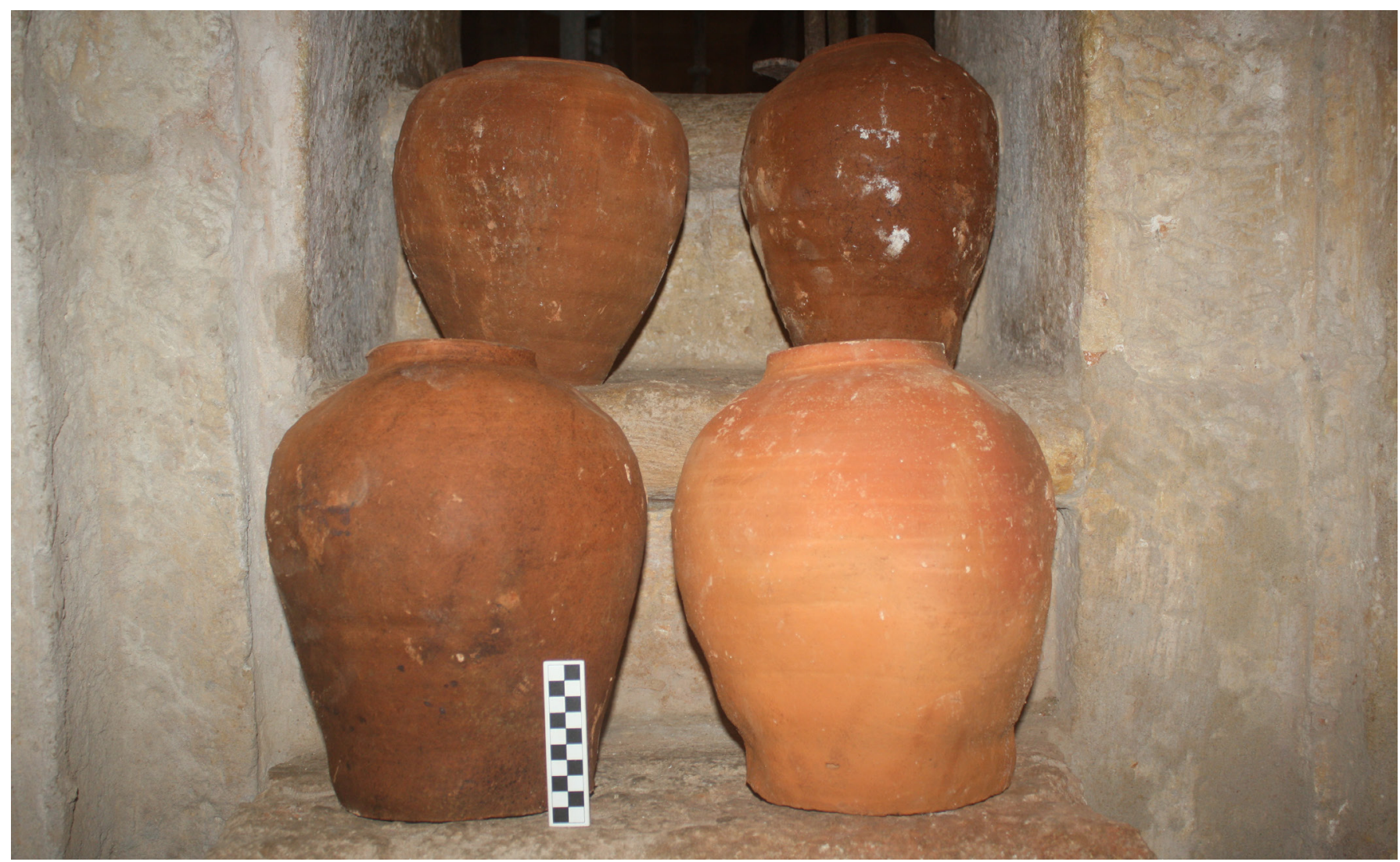

Figura 17. Muestrario de tinajas utilizadas como relleno de la bóveda de la Capilla de San Vicente de Ferrer. Estas fueron fabricadas exclusivamente para ese propósito.

A partir de este muro y sobre el polígono del ábside y transepto, se levantaron los muros de la segunda alzada y sobre los cuales se erigieron las bóvedas de sillería. Estos muros Tipo 3 se caracterizaron por fábricas hechas de tapia encadenada con mampostería y sillería. No obstante, mostraron algunas variantes para cada salón en términos de las combinaciones de aparejos y la altura de las tapias.

El cuerpo medio del ábside contiene cadenas de mampostería mucho más masivas, abarcando la mitad este del muro, y la mitad oeste con tapia, cercano a su adosamiento con el transepto. Por el contrario, en su muro este la tapia encadenada con mampostería alcanza su cuerpo alto. En el transepto, la fábrica de tapia encadenada con mampostería también alcanza su cuerpo alto. Todos los muros de carga del ábside y transepto fueron rematados por una viga de coronación de mampostería ordinaria con sillares. Esta viga, sirvió a su vez como muro frontal para las bóvedas norte y sur del transepto, así como la bóveda del ábside.

En estos muros se construyeron vanos de ventanas con una estética similar, pero con materiales y dimen- siones diferentes. En el muro este del ábside, sobre la primera alzada, se hicieron dos vanos de ventanas abocinadas hechos en ladrillos a soga y tizón. Mientras que en la primera alzada del muro sur se construyeron dos vanos de ventanas con arcos rebajados hechos en ladrillos a soga y tizón. Además, en el cuerpo alto del muro se construyó otra ventana abocinada hecha en sillería. Para el ábside, en su muro este se hizo una ventana de ladrillos con arco rebajado. En el muro sur se construyeron dos vanos de puerta y una ventana, ambos hechos en arcadas de ladrillos similares a las del ábside. En el cuerpo alto del transepto, en sus muros norte y sur, se hicieron dos ventanas abocinadas hechas en sillería (Figs. 18 y 19).

El análisis de las fábricas y sus materiales indican que el conjunto de bóvedas góticas que cubren el polígono de la iglesia del s. XVI fueron el resultado de un solo evento de construcción. El mismo está compuesto por una serie de arcos que arrancan desde las nervaduras en las esquinas y parte central de los muros de carga, así como de las pilastras de sillería que arrancan desde nivel de suelo en el crucero. Estos arcos sirvieron de solución 

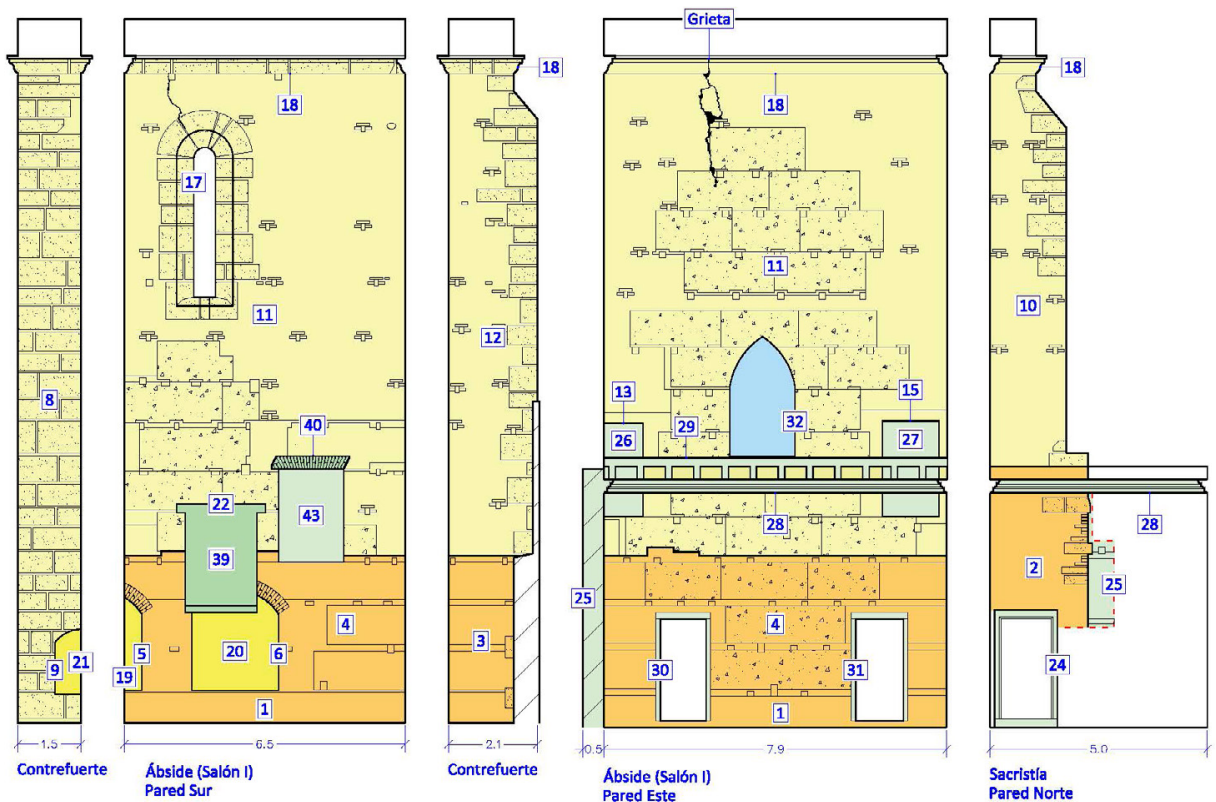

$\begin{array}{ll}\square \text { Etapa II, ca. 1530-35 } & \square \text { Etapa V, ca. 1769-74 } \\ \square \text { Etapa III, ca. 1548-82 } & \square \text { Etapa VI, ca. 1858-63 } \\ \square \text { Etapa III-IV } & \square \text { post. 1930 }\end{array}$

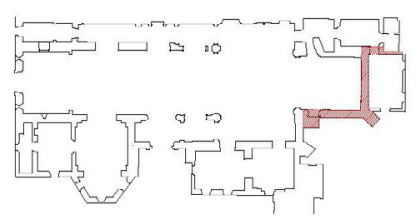

Figura 18. Alzadas de los muros este y sur del ábside. En anaranjado las fábricas que corresponden a la primera alzada de muros Tipo 1 y en amarillo fábricas de la segunda alzada de muros Tipo 2.
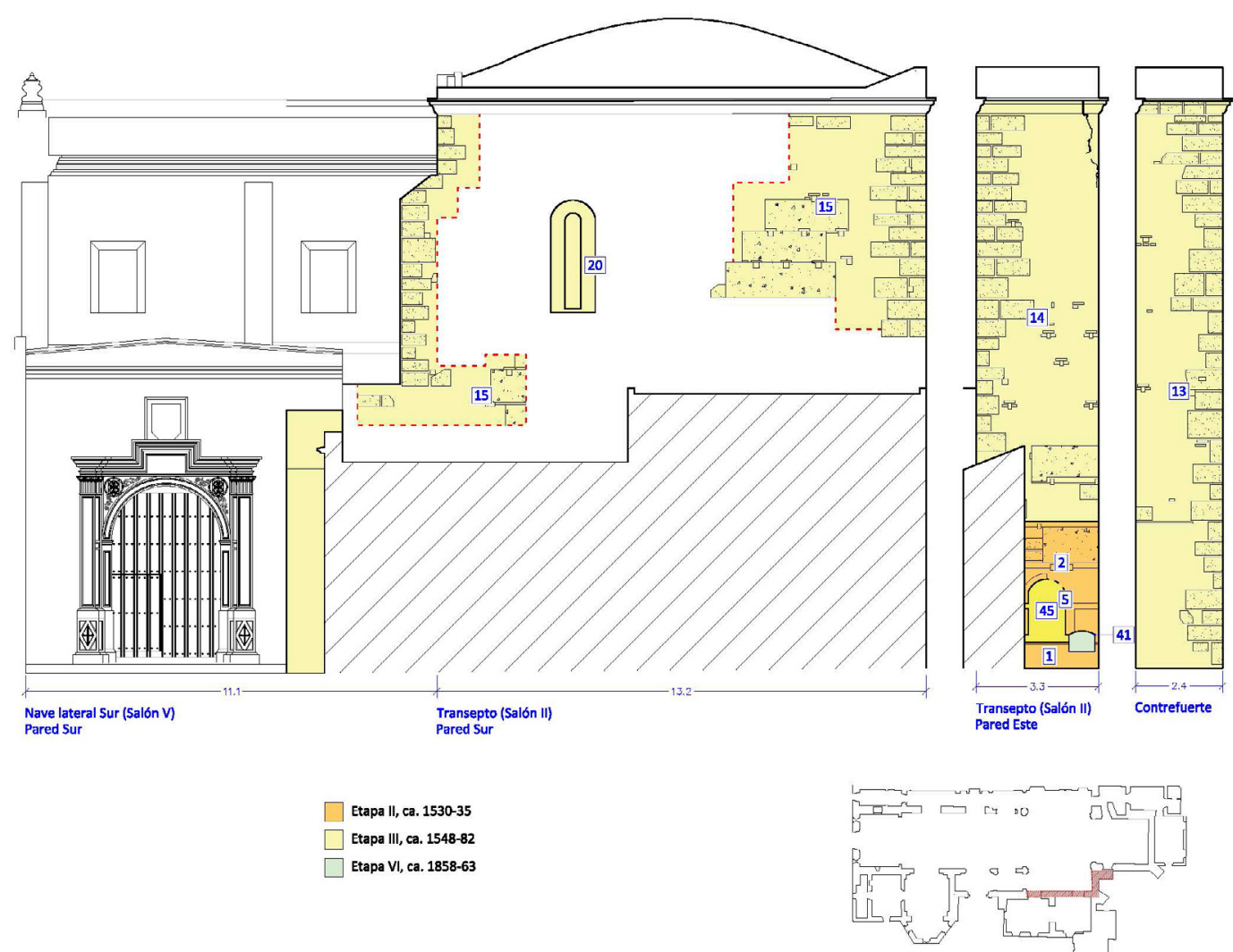

Figura 19. Alzadas del muro sur del transepto. En anaranjado las fábricas que corresponden a la primera alzada de muros Tipo 1 y en amarillo fábricas de la segunda alzada de muros Tipo 3. 
de continuidad entre las bóvedas que cubren las naves laterales y el ábside con la bóveda del crucero.

En el caso de las naves laterales, se levantaron otras bóvedas (norte y sur) adosadas a los arcos principales de la bóveda del crucero, que sirvieron como elemento de continuidad y de distribución de la carga. Mientras que para el ábside se aplicó el mismo principio de levantar su bóveda, adosándola al arco de la sección este del crucero.

A partir de 1582 culminan las obras de construcción de la iglesia, fisonomía caracterizada por una planta en forma de cruz, que mantuvo hasta la etapa 4 que abarcó el periodo entre 1635-1641, donde sufrió sus primeras grandes transformaciones.

\section{Etapa 4 (1635-1641): reformas del gobernador Mota Sarmiento}

Durante esta etapa la Iglesia San José sufrió los primeros cambios mayores en su fisonomía original. Hasta este momento la iglesia tenía forma de cruz achatada, donde su crucero estaba delimitado al área norte y sur por los muros Tipo 4 caracterizados por fábricas en mampostería ordinaria enchapada en sillares. Estas obras fueron realizadas durante la incumbencia del gobernador militar Íñigo Mota y Sarmiento (1635-1641), quien impulsó la construcción de otras importantes obras en la ciudad de San Juan. Entre estas la culminación del amurallamiento de la sección sur y suroeste de la ciudad, así como ampliaciones importantes tanto a San José y a la catedral.

El evento más significativo de esta etapa fue la construcción de la primera ampliación de la nave central adosada a la sección este, construida durante el evento anterior. Se levantaron sus muros de carga norte, sur y oeste levantados en una fábrica de mampostería careada y ripios con sus correspondientes vanos de ventanas, aspilleras y puertas. Esta ampliación abarcó el espacio actual que ocupa la nave central, incluyendo su coro, hasta el muro oeste, cuyo paramento exterior conforma la fachada principal. Se identificaron dos elementos que comprueban la ampliación de la nave central constituyó un solo evento de construcción: la fábrica de mampostería enripiada abarca los tres muros de carga que cierran el espacio muestran uniformidad de morteros y aparejos. Por otra parte, sus sistemas de adosamiento a la sección gótica de la iglesia construida en la etapa anterior son evidencia adicional de esta ampliación.

Esta extensión se adosó al extremo oeste de la sección de la nave central existente por medio de dos tipos de adosamiento. En el muro de carga sur se realizó un adosamiento simple entre ambos muros, mientras que en el muro de carga norte se realizó un adosamiento encastrado entre los vanos. La diferencia en simetría y los adosamientos entre ambos muros de carga permiten plantear dos posibles explicaciones: a) la construcción de esta sección del muro causó el derrumbe o daño considerable a la bóveda de la capilla Santa Rosa de Lima (adyacente a San Vicente Ferrer), provocando su reconstrucción, imitando aspectos del estilo gótico de la bóveda; b) la bóveda no fue construida para la etapa 4 si no que fue levantada junto con la extensión de la nave central, y posteriormente sufrió los daños estructurales que muestra actualmente (Fig. 20).

Durante esta etapa también ocurrió la construcción y adosamiento de la Capilla de Belén al paramento exterior del muro sur del transepto de la Iglesia San José. Este comenzó con la ampliación del vano para puerta y convertirlo en el acceso a la capilla de Belén. El estudio de fábricas de la capilla evidenció que esta fue construida en dos fases, donde el salón este fue levantado en una fábrica de mampostería ordinaria con una cúpula octogonal hecha en ladrillos. Los muros de carga norte de la capilla de Be-
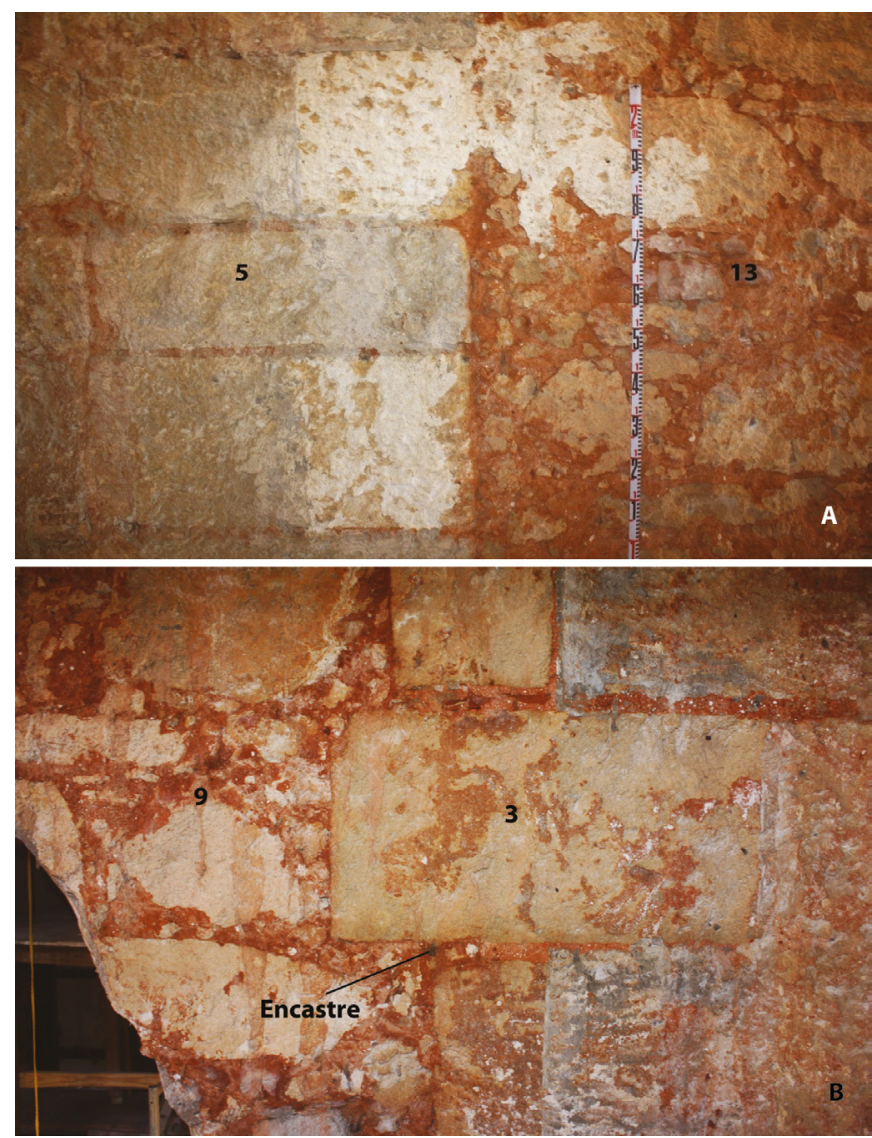

Figura 20. Sistemas de adosamiento entre la iglesia gótica y la nave central; A: adosamiento simple entre muros Tipo 4 (izquierda) y Tipo 6 (derecha), muro sur. B: adosamiento encastrado entre muros Tipo 6 (izquierda) y Tipo 4 (derecha). 

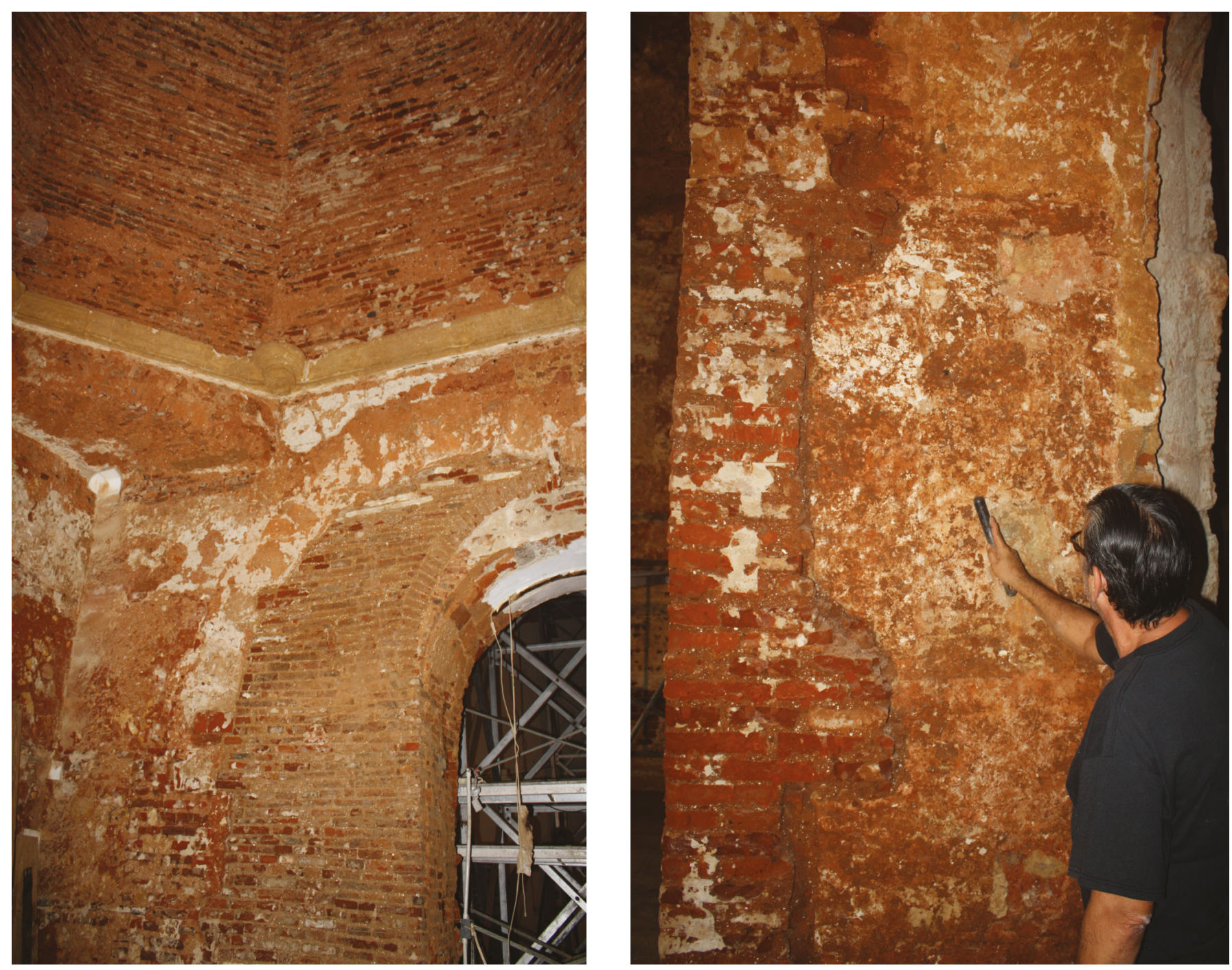

Figura 21. Elementos constructivos de la Capilla de Belén; izquierda: vista del muro norte, salón este con su bóveda octagonal. Derecha; adosamiento encastrado del muro norte de la capilla (salón oeste) al muro sur del transepto de San José.

lén fueron encastrados al transepto de San José. Mediante el estudio de fábricas se pudo comprobar que el salón este se edificó primero ya que se observa el adosamiento simple en la sección sur, entre lo que fue la fachada oeste de la capilla original y el muro sur del nuevo salón (Fig. 21). El salón oeste fue construido durante las ampliaciones hechas por los jesuitas durante la etapa 6 .

Una vez levantada la capilla de Belén, se le adosó un contrafuerte hecho en mampostería encadenada con sillares en la interfase entre su muro de carga este y la esquina sureste del transepto. Cabe destacar que, para la construcción de este contrafuerte, así como otros elementos de la capilla de Belén, se imitaron en menor escala los trabajos de sillería de la iglesia del s. XVI en los arcos y cornisas. También se realizaron reparaciones en el cuerpo bajo del paramento exterior del muro del transepto. Específicamente se aplicó un engrosamiento de mortero y tosca de arenisca. Posiblemente, esto provocó la pérdida de material de las tapias, y el adosamiento de la capilla de Belén.

Otro evento significativo fue la construcción de la capilla de Nuestra Sra. del Rosario. Contrario a lo planteado anteriormente, esta estructura no fue autónoma del resto del inmueble principal levantada previamente en la nave central. Los análisis estratigráficos evidenciaron que esta capilla fue construida posteriormente a la nave central y adosada a su muro sur. Para su acceso desde la nave central se abrió un monumental vano de puerta hecho en ladrillos que cortó la fábrica de mampostería careada y ripios, así como el vano existente. Una vez construido el arco de este vano, se cegó la ven- 

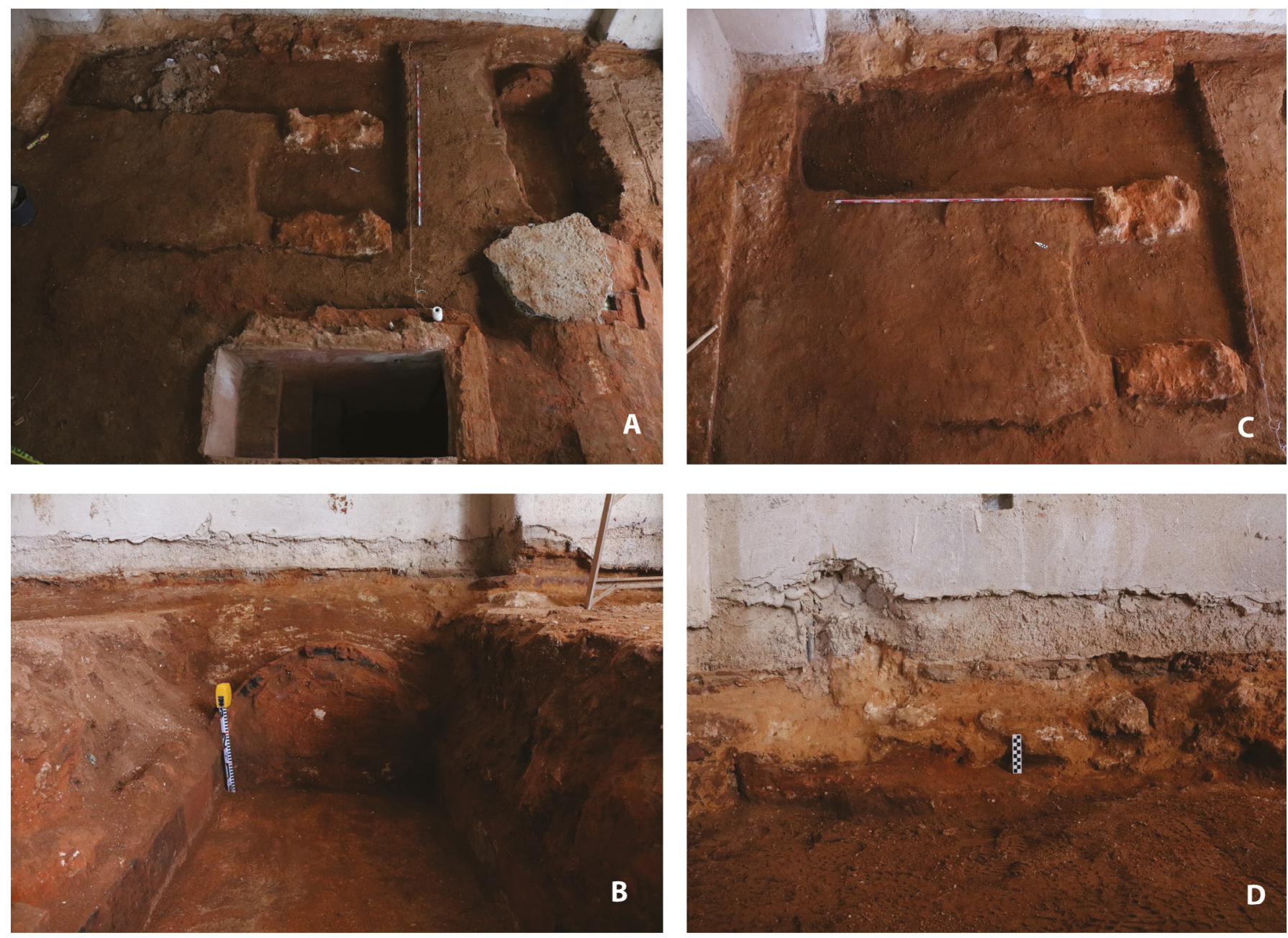

Figura 22. Varias perspectivas de los elementos descubiertos en la Capilla del Rosario; A: vista de planta general con la entrada de la cripta en primer plano; B: vista hacia el este de nicho hecho en ladrillos impactado por trabajos previos; C: cimientos en mampostería ordinaria asociados a estructura desconocida ca. 1548-82; D: secuencia de rellenos y pisos de argamasa asociados a la construcción de la capilla.

tana con mampostería ordinaria. También se adosaron los muros de carga este y oeste de Rosario a la fachada Sur de la nave central.

Debido a que los paramentos de esta capilla ya habían sido restaurados no se pudieron observar y caracterizar las fábricas de los muros de carga. Sin embargo, durante la documentación arqueológica se pudieron identificar elementos constructivos, así como impactos contemporáneos entre los que destacan (Figs. 22-24):

1. Cimentación hecha en mampostería ordinaria y sillares. Posiblemente asociada para las etapas II-III (1530-1582).

2. Remanentes del piso de argamasa y cimentación en mampostería ordinaria. Asociada a la construcción de la nave central para la etapa IV ( $c a$. 1635-1641).
3. Cripta hecha en ladrillos asociada a la ampliación de la capilla para la etapa V (ca. 1769-1774).

4. Trincheras excavadas durante intervención posterior asociadas a década de 1970.

\section{G. Etapa 5 (1769-1774): culminación de la nave central}

El evento que marcó esta etapa fue la construcción de la monumental bóveda de cañón de $9,4 \times 30 \mathrm{~m}$ y sus estructuras relacionadas. Este incluyó el levantamiento de sus muros de carga, hechos en mampostería ordinaria, sus vanos de ventanas y los contrafuertes adosados (cinco de ambos en cada muro de carga). Estos muros fueron levantados sobre los que sostenían el techado de madera a dos aguas, el muro de carga oeste, y la monumental 


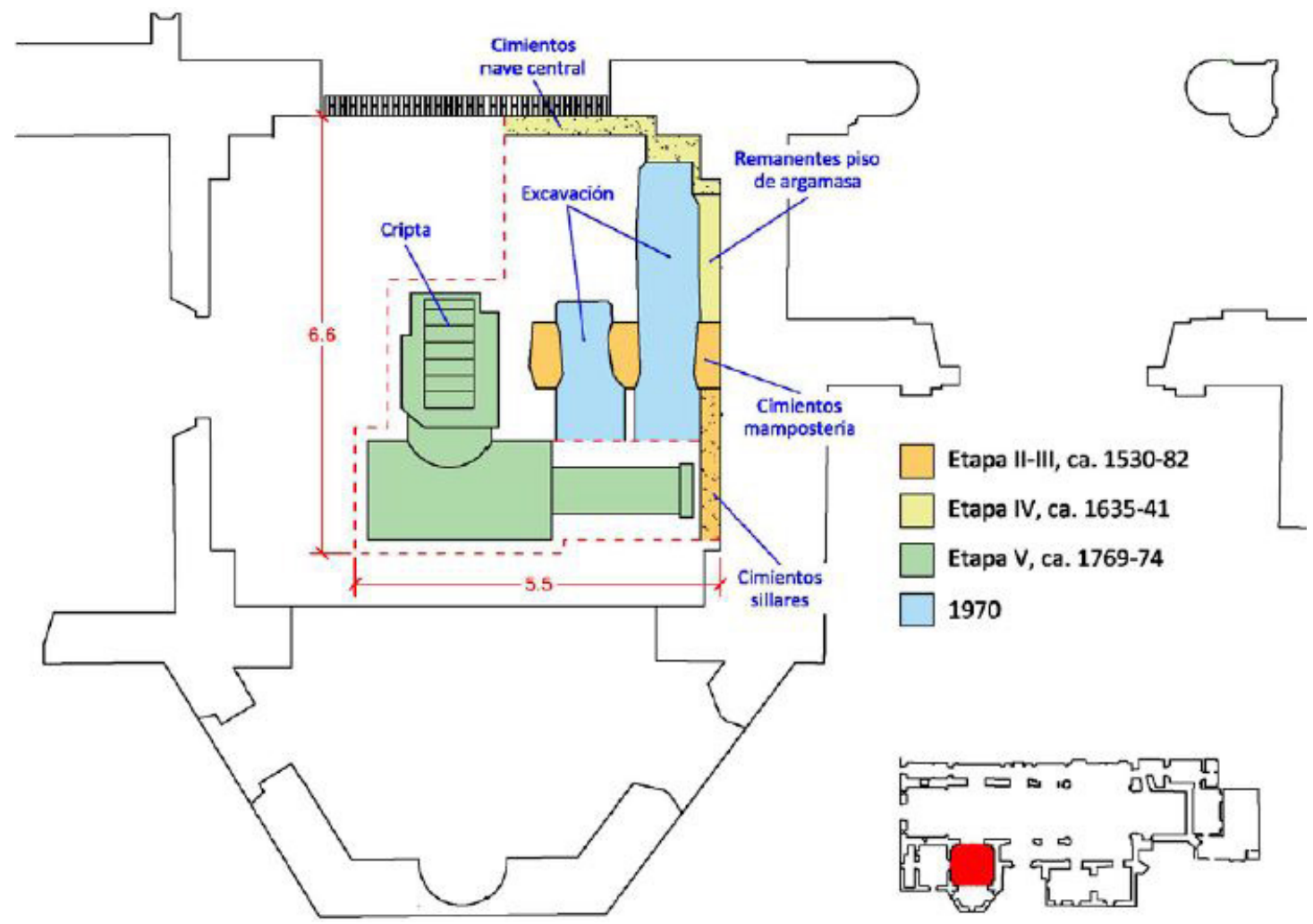

Figura 23. Secuencia de los principales eventos constructivos asociados a la Capilla del Rosario.
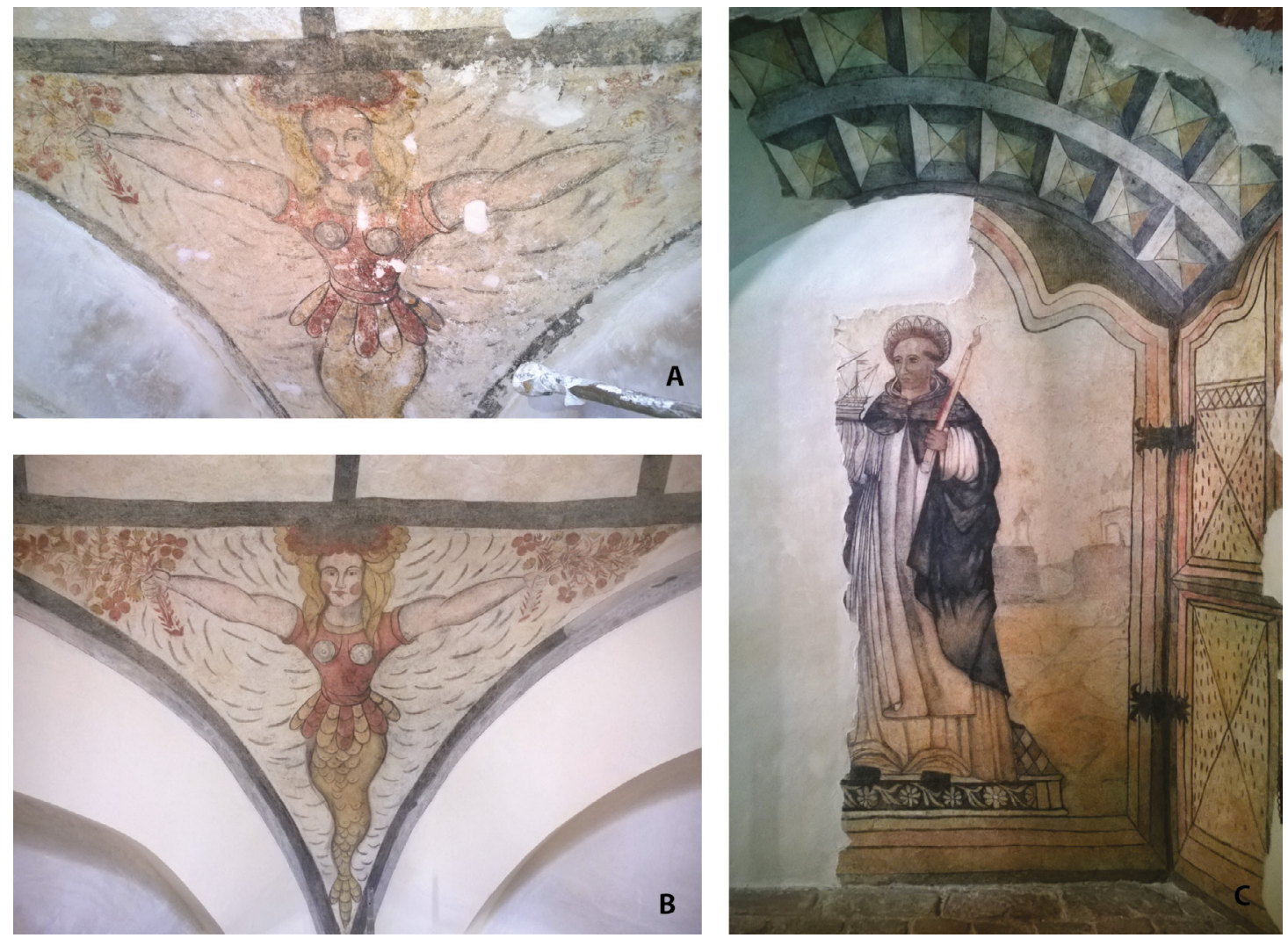

Figura 24. Detalle de frescos restaurados; A: sirena descubierta en la Capilla del Rosario; B: pintura luego de su restauración; C: pintura restaurada de San Telmo, patrono de los marineros, muro norte del transepto. 

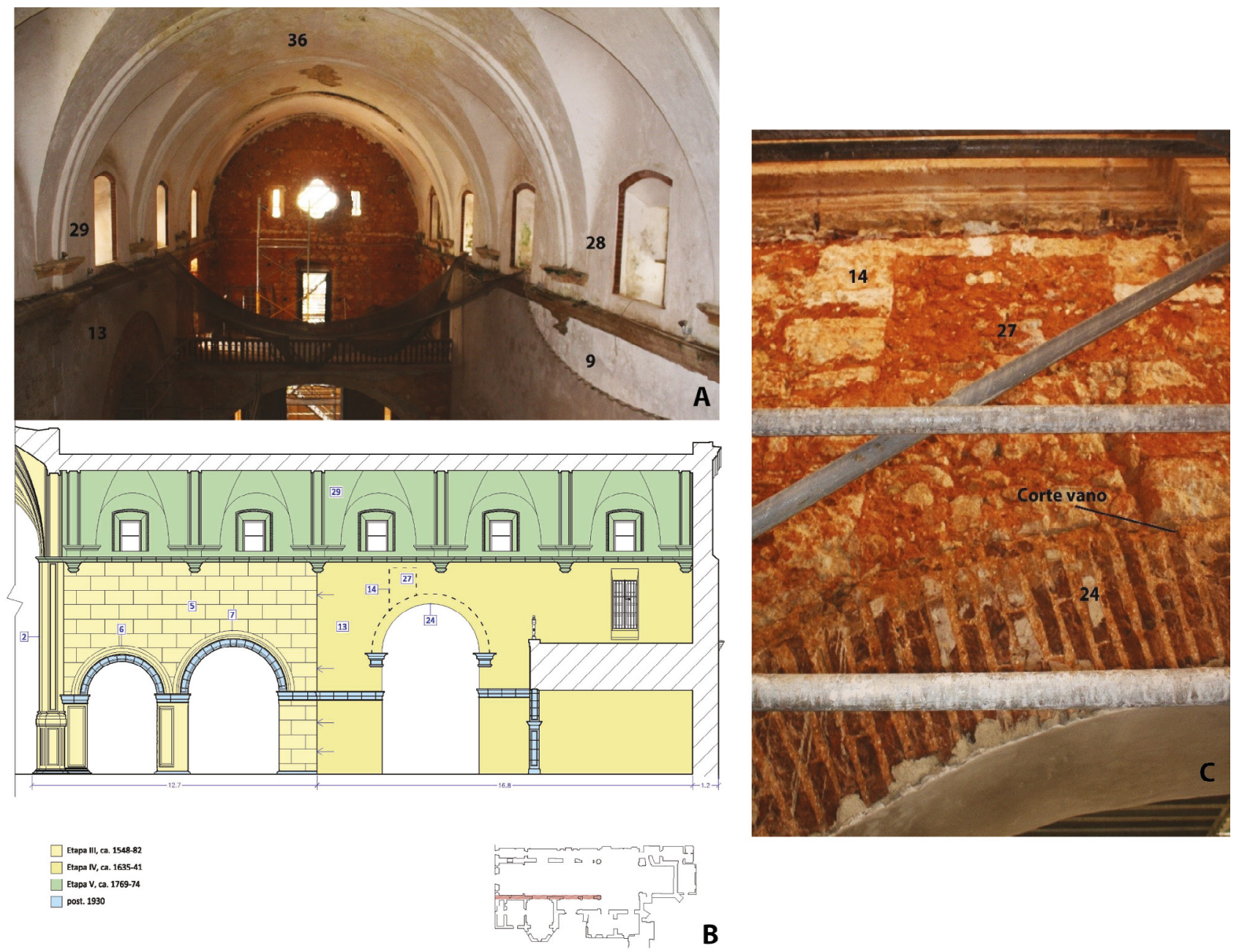

B

Figura 25. Nave central; A: vista de la nave central y la bóveda de ladrillos asociada a la Etapa 5; B: alzada sur de la nave central que muestra sus etapas constructivas; C: vista del arco de acceso a Rosario y corte de la ventana para la construcción del arco.

bóveda de cañón con ladrillos adosada en su extremo este a la bóveda gótica del crucero (Fig. 25).

Varios años después, fray Íñigo Abbad y Lasierra, en su Historia geográfica, civil y natural de la isla de Puerto Rico de 1788 (2002) hace una muy breve descripción de la iglesia donde corrobora la culminación de los trabajos de construcción de la bóveda de medio punto: "Hay un convento de religiosos Franciscos, otro de Dominicos y otro de monjas del Carmen calzados: los dos primeros son edificios más grandes que hermosos, aunque sus iglesias y claustros están con arco y bien fabricados". ${ }^{11}$

\footnotetext{
${ }^{11}$ Abbad y Lasierra, Íñigo 2002. Historia civil, geográfica y natural de la isla de San Juan Bautista de Puerto Rico [1788]. Anotada en la parte histórica y continuada en la estadística y económica por José Julián Acosta. Ediciones Doce Calles. Madrid. P.283.
}

Estas mejoras se les atribuyen a reparaciones ordenadas por el rey Carlos III como consecuencia de daños ocasionados por el azote de varios huracanes. Las obras estuvieron a cargo del Mariscal Alejandro O'Reilly (Tobar 1963, citado en Robiou 2004: 12) quien estuvo a cargo de la modernización del sistema defensivo de la plaza de San Juan entre 1765-1771 (Rodríguez López y Rivera Groennou 2018: 37-38).

\section{H. Etapa 6 (ca. 1858): la Compañía de Jesús}

Con la llegada de la Compañía de Jesús se inició un periodo de construcciones y mejoras que abarcaron distintas áreas del inmueble. Junto con otras técnicas y materiales, uno de los materiales de construcción característicos del s. XIX es el ladrillo, el cual vemos utili- 
zado ampliamente en las obras de reparaciones. Las de mayor envergadura estuvieron relacionadas con la construcción de la sacristía y estructuras relacionadas con el paramento exterior del muro este del ábside. Estas involucraron la apertura de un vano de puerta en el adosamiento de sus muros de carga norte y sur hechos en mampostería ordinaria, el cegamiento de las ventanas, la apertura de vanos para armarios, y una ventana ojival en la parte central del muro este del ábside sobre el nivel de su cubierta.

Finalmente, durante esta etapa se construyó el salón oeste de la Capilla de Belén en una fábrica de mampostería ordinaria con verdugadas encadenada en ladrillos con una bóveda de medio de punto. Los muros de carga norte de la capilla fueron encastrados al transepto de San José. Durante estas obras se destruyó la antigua cripta del s. XVII, además del cegamiento de varios vanos de ventanas.

Las estructuras de vano hechas en ladrillos, especialmente los arcos adintelados, son característicos a lo largo del s. XIX. Otras obras realizadas con ladrillo fueron la construcción del pretil que corona los muros del ábside y transepto, aparejados a soga y tizón, y el cegamiento del nicho en el muro este del transepto.

También durante esta etapa se realizaron mejoras y ampliaciones de los diferentes altares. En especial, los altares de las capillas de San Vicente y del lado sur del transepto fueron restaurados. Para estas mejoras se hizo una apertura y/o ampliación de nichos en fábrica de mampostería ordinaria, así como corte de los muros de carga para la instalación de altares de madera y otros elementos decorativos (Fig. 26).
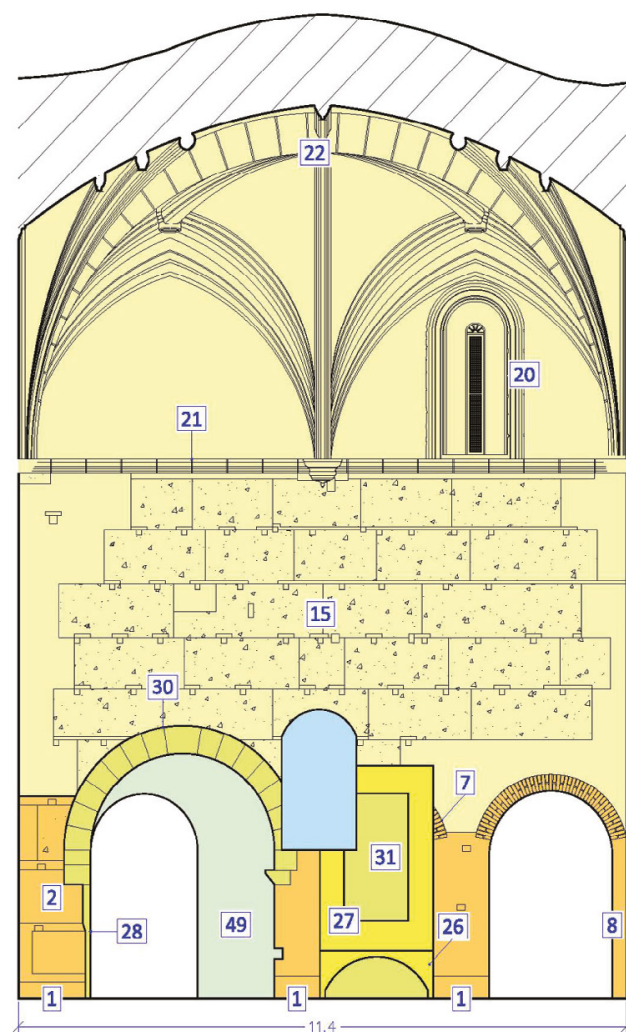

$$
\begin{aligned}
& \text { Etapa II, ca. 1530-35 } \\
& \text { Etapa III, ca. 1548-82 } \\
& \text { Etapa III-IV } \\
& \text { Etapa IV, ca. 1635-41 } \\
& \text { Etapa VI, ca. 1858-63 } \\
& \text { post. } 1930
\end{aligned}
$$

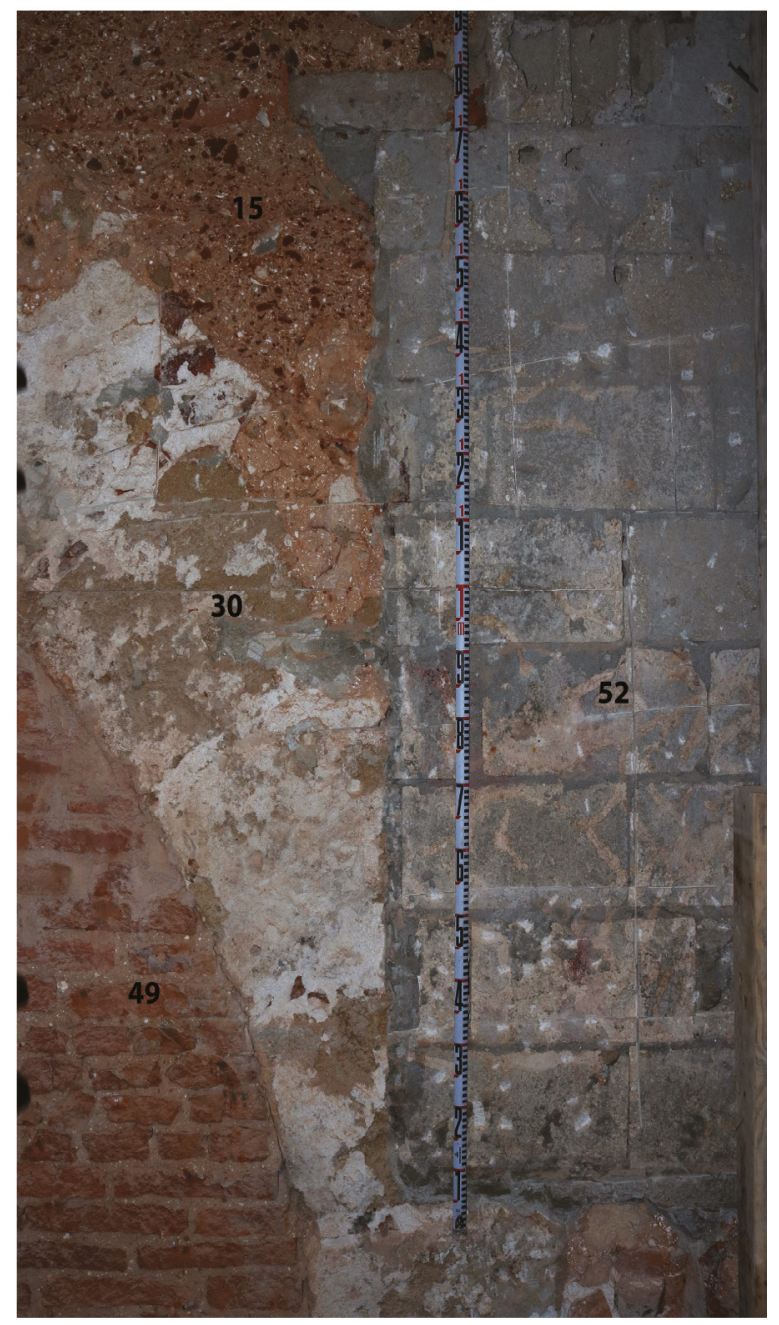

Figura 26. Alzado sur del paramento interior del transepto. Izquierda: en anaranjado las fábricas que corresponden a la primera alzada y en amarillo fábricas de la segunda alzado y el resto de las modificaciones posteriores. Derecha: detalle de corte para nicho tapiado en bloques de cemento. 


\section{Etapa 7 (ca. 1930-presente)}

Para la época contemporánea se documentó una serie de reparaciones en materiales constructivos contemporáneos como el cemento Portland, bloques de cemento y ladrillos trabados con cemento. Principalmente, estas obras consistieron en cegamientos de las ventanas en el ábside y la reparación de las vigas de la cubierta de la sacristía hecha en cemento armado. En el transepto se abrió un nicho cegado posteriormente con bloques de cemento. En la nave lateral norte y nave central se hicieron reparaciones en cemento armado y se reforzaron las pilastras de sillería con bloques de cemento y ladrillos trabados con cemento.

\section{CONCLUSIONES}

Este trabajo presenta nueva evidencia con importantes avances en lo que respecta el estudio de las técnicas constructivas empleadas en San Juan de Puerto Rico desde inicios de la conquista española en el s. XVI hasta principios del s. XX. La implementación teórica y metodológica de la perspectiva de la Arqueología de la Arquitectura ha sido crucial para poder descubrir el proceso de desarrollo y transformación constructiva de este monumento. El estudio de fábricas y análisis de las relaciones secuenciales de las diversas estructuras de la Iglesia San José, han sido fundamentales para la corroboración de la documentación histórica y el análisis estilístico.

La Iglesia San José ejemplifica, al igual que otros monumentos sanjuaneros como Casa Blanca, un panorama de desarrollo constructivo y urbano que abarcó la ciudad completa con técnicas y materiales identificables cronológicamente las cuales representan tendencias y posibilidades de acuerdo con los recursos disponibles. En este caso se identificaron siete etapas constructivas con ocho tipos de fábricas, algunas de ellas compuestas de técnicas mixtas y caracterizadas por cadenas y cajones de diferentes materiales como piedra y ladrillos. Resultan notables las técnicas mixtas asociadas a la tapia, una de las fábricas más antiguas y emblemáticas empleadas para edificaciones de la primera mitad del s. XVI. Descrita consistentemente en las fuentes históricas, fue identificada como una de las técnicas principales en la construcción de la iglesia gótica. El empleo de esta técnica y las similitudes entre las tapias identificadas otros edificios como Casa Blanca, nos confirman el vínculo entre ambas estructuras a través de la familia Ponce de León Troche.
El exquisito trabajo en sillería de las bóvedas góticas es sin lugar a duda, uno de sus atributos más destacables. Igualmente, los elementos estructurales hechos en sillería para las técnicas mixtas, y otros componentes como arcos, vanos, cornisas, entre otros, aportan a su majestuosidad y valor arquitectónico. De la misma forma, la documentación ha puesto en perspectiva los diferentes contextos históricos de limitaciones de fondos y recursos que caracterizó el proceso la edificación de muchas de estas estructuras emblemáticas, San José incluida.

No obstante, desde una perspectiva más amplia, los trabajos de Arqueología de la Arquitectura en San José han evidenciado las grandes limitaciones que implican la aplicación de intervenciones que no integran estudios estratigráficos ni análisis secuenciales de estos inmuebles. Este caso dramatiza lo que había sido una práctica bastante difundida en las intervenciones en edificaciones en el Viejo San Juan durante la segunda mitad del s. XX: una edificación intervenida en numerosas ocasiones en donde se contaba con muy limitada información de carácter científico.

Ya desde finales del s. XX e inicios del s. XXI es cuando finalmente se comienzan a integrar en estas intervenciones equipos multidisciplinarios que incluían arquitectos, arqueólogos, conservacionistas, donde existía una estricta división entre los roles asignados entre estos profesionales. Es decir, se relegaba el papel de la arqueología a interpretar todo lo que estuviera relacionado al subsuelo, mientras que todo lo que implicara elementos del edificio se reservaba a arquitectos y conservacionistas. El problema principal no se limitaba simplemente a esta estricta "división de roles" sino a que ninguno de estos profesionales integraba a sus trabajos los preceptos metodológicos de Arqueología de la Arquitectura ni combinaba sus hallazgos de forma integral. Es decir, la caracterización de unidades estratigráficas, su muestreo sistemático, el establecimiento de secuencias estratigráficas y las relaciones entre sus elementos arquitectónicos.

En ese sentido, el haber abordado las diferentes problemáticas planteadas para el estudio de San José desde una perspectiva estratigráfica permitió desenmarañar múltiples interrogantes y conclusiones basadas en información incompleta asumidas como verdades absolutas. El estudio de sus fábricas y sus secuencias estratigráficas ha aportado grandemente a la compresión y contextualización de la información documental e histórica previamente conocida. Esto permitió más aún, poder abordar su estudio desde una perspectiva basada en criterios científicos que señaló objetivos claros que sobrepasaron la discusión estilística arquitectónica. 
Es precisamente, partiendo de este trasfondo, que toman mayor relevancia nuestra intervención arqueológica en San José, ya que, por una parte, aportó valiosa información sobre sus aspectos constructivos y secuenciales previamente desconocidos que contextualizan la información histórica. Por otra parte, proveyó una perspectiva más a tono con lo que debe ser parte de los criterios y métodos científicos usados para la intervención de inmuebles patrimoniales.

\section{AGRADECIMIENTOS}

Queremos agradecer al arquitecto Jorge Rigau por permitirnos formar parte del equipo de restauración de San José para el estudio estratigráfico del inmueble y por su confianza en implementar nuestras recomendaciones para llevarlo a cabo. Al Patronato de Monumentos de San Juan y su presidente Ricardo González por acometer este complejo y necesario proyecto de restauración y permitirnos integrarnos al proyecto. También al arquitecto Leandro Cámara por las productivas discusiones que sostuvimos sobre nuestras interpretaciones del desarrollo constructivo de la iglesia.

\section{FICHA TÉCNICA}

Todas las fotos y figuras producidas durante los trabajos de campo y modificadas para la producción del informe técnico sometido al Patronato de Monumentos de San Juan, reproducidas en este escrito, son de la autoría de los autores de este artículo. Para las figuras que incluyen planos, estas fueron generadas utilizando de referencia los planos arquitectónicos hechos por el equipo dirigido por el arquitecto Jorge Rigau.

\section{ANEXO: ARCHIVO COMPLEMENTARIO}

En el sitio web de la revista está disponible un archivo complementario en formato Excel que contiene: Caracterizaciones de UEM y diagramaciones Harris.

\section{FUENTES}

Abbad y Lasierra, Í. 2002. Historia civil, geográfica y natural de la isla de San Juan Bautista de Puerto Rico [1788]. Anotada en la parte histórica y continuada en la estadística y económica por José Julián Acosta. Ediciones Doce Calles, Aranjuez.
Alegría Gallardo, R. 2009: Editor, Documentos históricos de Puerto Rico, Volúmenes I-V. Centro de Estudios Avanzados de Puerto Rico y el Caribe, San Juan.

Caro Costas, A. 1989: "Descripción de la Isla y Ciudad de Puerto Rico y de su vecindad y poblaciones, presidio, gobernadores y obispos, frutos y minerales" [1647], Editora, Antología de lecturas de historia de Puerto Rico, pp. 319-368. Editora Corripio, Santo Domingo.

Coll y Toste, C. 1914: "Memoria y descripción de la isla de San Juan de Puerto Rico mandada a hacer por S.M. el Rey Don Felipe II en el año 1582", Editor, Boletín Histórico de Puerto Rico, Volumen 1, Tomo 1, pp. 75-91. Tip. Cantero, Fernández \& Co. San Juan.

Damiani Cósimi, J. 1994 "Información referente al Partido de Puerto Rico" [1530], Editor, Cuadernos de Investigación Histórica, 1, pp. 37-154. Universidad de Puerto, Río Piedras.

\section{BIBLIOGRAFÍA}

Azkarate Garai-Olaun, A., Caballero Zoreda, L. y Quirós Castillo, J. A. 2002: "Arqueología de la Arquitectura: definición disciplinar y nuevas perspectivas", Arqueología de la arquitectura, 1, pp. 7-10. http://arqarqt. revistas.csic.es/index.php/arqarqt/article/view/1

Brogiolo, G. P. 2002: “L'Archeologia dell'architettura in Italia nell'ultimo quinquenio (1997-2001) L'Archeologia dell'architettura in Italia nell'ultimo quinquennio (1997-2001)", Arqueología de la Arquitectura, 1, pp. 19-26. https://doi.org/10.3989/arq.arqt.2002.3

Buschiazzo, M. J. 1955: Estudio sobre monumentos históricos de Puerto Rico. Junta de Planificación de Puerto Rico, San Juan.

Caballero Zoreda, L. 2002: "Sobre límites y posibilidades de la investigación arqueológica de la arquitectura. De estratigrafía a modelo histórico", Arqueología de la Arquitectura, 1, pp. 83-100. https://doi. org/10.3989/arq.arqt.2002.8

Campo Lacasa, M. C. 1961: "Las iglesias y conventos de Puerto Rico en el siglo XVIII", Revista del Instituto de Cultura Puertorriqueña, 13, pp. 14-19.

Castro Arroyo, M. de los A. 1980: Arquitectura en San Juan de Puerto Rico (s. XIX). Editorial Universitaria, Universidad de Río Piedras, Recinto de Río Piedras, San Juan, Puerto Rico.

Cerdá, M. y García Bonafé, M. 1995: Enciclopedia valenciana de arqueología industrial. Edicions Alfons el Magnanim / Associació d'Arqueologia Industrial, Valencia.

Cuesta Mendoza, A. 1946: Los dominicos en el Puerto Rico colonial (15211821). Publicaciones Gaviota, México.

Damiani Cósimi, J. 1994 "Estratificación social, esclavos y naborías en el Puerto Rico minero del siglo XVI", Cuadernos de Investigación Histórica, 1, pp. 1-37.

Flores Saso, V. 2006: Obra de fábrica de la Catedral de Santo Domingo, Primada de América. Sus 20 años de construcción, desde 1521-1541. Tesis doctoral inédita presentada en la Universidad de Michoacán, México.

Fundación por la Arquitectura. 2010: Iglesia San José, vista desde el andamio. Editorial Revés, San Juan.

Graciani García, A. y Tabales Rodríguez, M. A. 2008: “El tapial en el área sevillana. Avance cronotipológico estructural", Arqueología de la Arquitectura, 5, pp. 135-158. https://doi.org/10.3989/arq.arqt.2008.93

Harris, E. 1991: Principios de estratigrafia arqueológica. Editorial Crítica, Barcelona.

Hostos, A. 1979: Historia de San Juan ciudad murada. Instituto de Cultura Puertorriqueña, San Juan, Puerto Rico.

López Sotomayor, D. 2000: La Real Audiencia Territorial, San Juan de Puerto Rico. Proyecto de Arqueología Histórica. Informe preparado para la Oficina Estatal de Conservación Histórica, San Juan.

Mileto, C. y Vegas, F. 2003: "El análisis estratigráfico constructivo como estudio previo al proyecto de restauración arquitectónica: metodología y aplicación", Arqueología de la Arquitectura, 2, pp. 189-196. https://doi. org/10.3989/arq.arqt.2003.46 
Murga Sanz, V. 1964: Cedulario puertorriqueño. Historia Documental de Puerto Rico, Volumen III. Tomo II (1518-1525), pp. 142-144. Universidad de Puerto Rico, Río Piedras.

Parenti, R. 1992: "Fonti materiali e lettura stratigrafica di un centro urbano: i risultati di una sperimentazione "non tradizionale"”, Archeologia Medievale, XIX, pp. 7-62.

Quirós Castillo, J. A. 2002: "La arqueología de la arquitectura en España", Arqueología de la Arquitectura, 1, pp. 27-38. https://doi.org/10.3989/arq. arqt.2002.4

Rivera Fontán, J. A., Rodríguez López, J. A. y Rivera Groennou, J. M. 2011: "Investigaciones Arqueológicas en Casa Blanca y sus entornos", $9^{\circ}$ Encuentro de Investigadores de Arqueología y Etnohistoria, pp. 86-106. En homenaje a Ricardo Alegría. Programa de Arqueología y Etnohistoria, Instituto de Cultura Puertorriqueña, San Juan.

Rivera Fontán, J. A., Rodríguez López, J. A. y Rivera Groennou, J. M. 2013: “Arqueología Pública: La ciencia al servicio del pueblo. Nuevos descubrimientos arqueológicos y ofrecimientos museográficos en Casa Blanca", Revista Instituto de Cultura Puertorriqueña, 24, pp. 5-24. Segunda serie.

Rivera Fontán, J. A., Rodríguez López, J. A. y Rivera Groennou, J. M. 2014: Historia constructiva de Casa Blanca: documentación de materiales arqueológicos y análisis de morteros de fábrica. Informe Final. Sometido a la Oficina Estatal de Preservación Histórica, San Juan.

Rivera Groennou, J. M., Rodríguez López, J. A. y Rivera Fontán, J. A. 2011: "La Casa Blanca: cuatro siglos de construcción española en la ciudad de San Juan de Puerto Rico, siglos XVI al XIX", en S. Huerta, I. Gil Crespo, S. García y M. Taín (eds.), Actas del Séptimo Congreso Nacional de Historia de la Construcción, pp. 1181-1191. Santiago 26-29 octubre 2011. Instituto Juan de Herrera, Madrid.

Rivera Groennou, J. M., Rodríguez López, J. A. y Rivera Fontán, J. A. 2015: "Caracterización petrográfica de las tapias y morteros utilizados en la construcción de Casa Blanca durante los siglos XVI-XVIII", 25th International Congress of Caribbean Archaeology, pp. 762-790. Publicación del Instituto de Cultura Puertorriqueña, el Centro de Estudios Avanzados de Puerto Rico y el Caribe y la Universidad de Puerto Rico, Recinto de Río Piedras. San Juan.

Robiou Lamarche, S. 2004: La iglesia San José: historia, imagen y arquitectura sagrada de un monumento. Investigación efectuada para el curso "Imagen e historia: los monumentos como documentos". Centro de Estudios Avanzado de Puerto Rico y el Caribe, San Juan, Puerto Rico. Manuscrito recuperado de: http://edicionesdigitales.info/biblioteca/srliglesiasanjose.pdf

Rodríguez, M. s. a.: "La arqueología de los conventos religiosos: excavaciones en el Convento de los Dominicos de San Juan, Puerto Rico", $6^{\circ}$ Encuentro de Investigadores de Arqueología y Etnohistoria, pp. 84-91. Programa de Arqueología y Etnohistoria, Instituto de Cultura Puertorriqueña, San Juan.

Rodríguez López, J. A. y Rivera Groennou, J. M. 2016: Arqueología de la Arquitectura de la Iglesia San José, San Juan, Puerto Rico. Informe Final. Sometido a los arquitectos Leandro Cámara y Jorge Rigau. Patronato de Monumentos de San Juan Inc.

Rodríguez López, J. A. y Rivera Groennou, J. M. 2018: Archaeological Assessment Phase IA-IB. Santa Elena Gunpowder Magazine Retaining Wall Project. San Juan National Historic Site, San Juan, Puerto Rico.

Rodríguez López, J. A, Rivera Groennou, J. M. y Rivera Fontán, J. A. 2015: "Arqueología de la arquitectura de Casa Blanca: nuevos descubrimientos y aportaciones metodológicas en la intervención de estructuras patrimoniales", 25th International Congress of Caribbean Archaeology, pp. 817-842. Publicación del Instituto de Cultura Puertorriqueña, el Centro de Estudios Avanzados de Puerto Rico y el Caribe y la Universidad de Puerto Rico, Recinto de Río Piedras. San Juan.

Tabales Rodríguez, M. A. 1997: “Análisis arqueológico de paramentos. Aplicaciones en el patrimonio edificado sevillano", Spal. Revista de Prehistoria y Arqueología, 6, pp. 263-295. https://doi.org/10.12795/spal.1997.i6.15

Tabales Rodríguez, M. A. 2002: “Arqueología y rehabilitación en Sevilla. Desarrollo metodológico y práctico", Arqueología de la Arquitectura, 1, pp. 193-206. https://doi.org/10.3989/arq.arqt.2002.15

Tobar, E. 1963: Iglesia de San José: templo y museo del pueblo puertorriqueño. Imprenta La milagrosa, San Juan. 